2. To: (Receiving Organization)
Storage and Disposal
5. Proj./Prog./Dept./Div.:
TWRS/Environmental/Environme
ntal Permits and Policies

8. Originator Remarks:

Document submitted for approval and release.
3. From: (originating Organization) TWRS Environmental Permits and Policies

6. Design Authority/ Design Agent/Cog. Engr.:
C. A. Petersen

4. Related EDT NO.:

605603

7. Purchase Order No.:

$$
\text { N/A }
$$

9. Equip. /Component No.: $\mathrm{N} / \mathrm{A}$

10. System/Bldg./Facility:

11. Receiver Remarks: 11A. Design Basel ine Document? [] Yes [X] No
Grout

12. Major Assm. Dwg. No.:

N/A

13. Permit/Permit Application No.: $N / A$

14. Requi red Response Date: 09/05/97

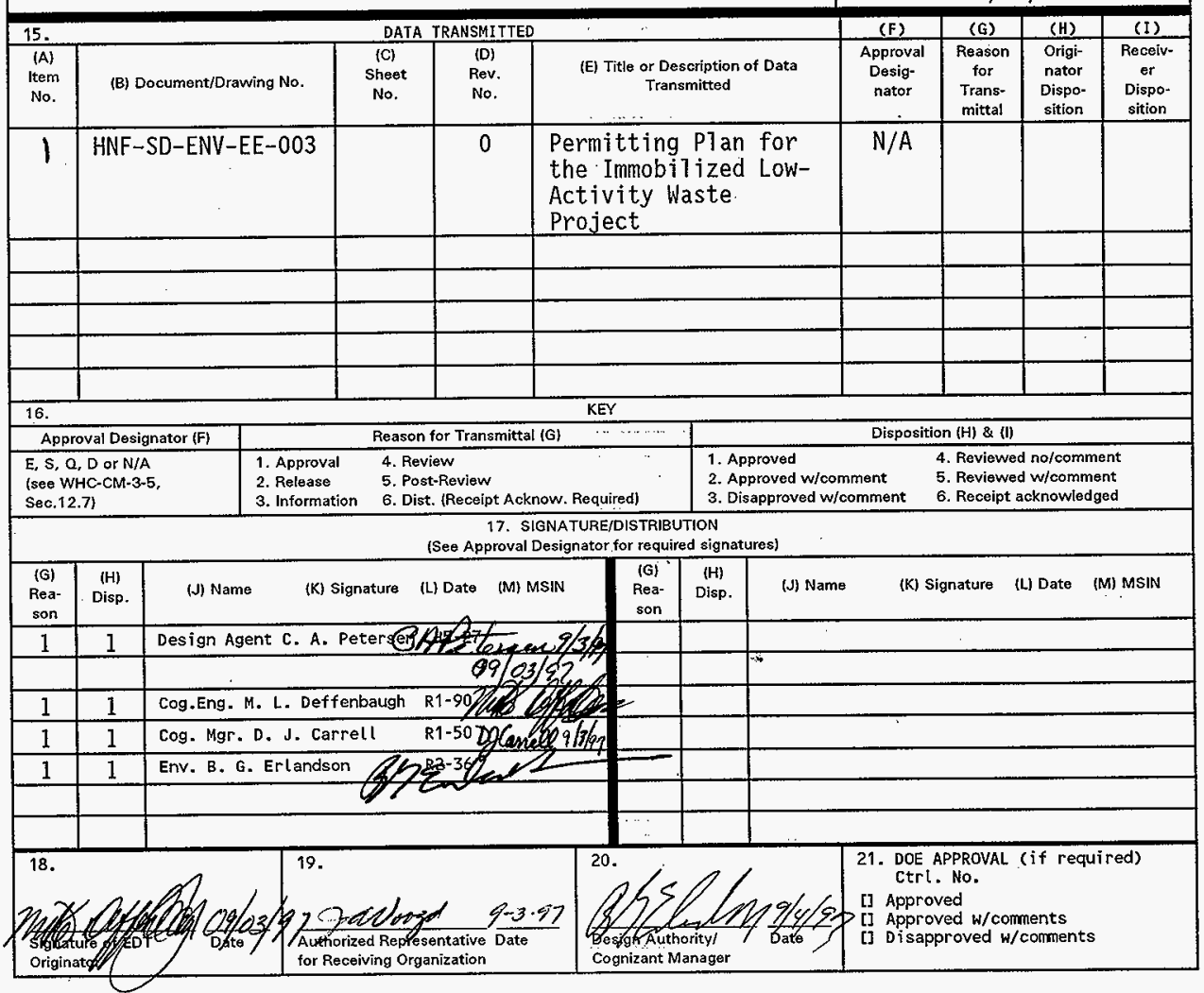




\section{Permitting Plan for the Immobilized Low-Activity Waste Project}

\section{L. Deffenbaugh}

Lockheed Martin Hanford Corporation, RichTand, WA 99352

U.S. Department of Energy Contract DE-AC06-96RL13200

$\begin{array}{lll}\text { EDT/ECN: } & 605603 & \text { UC: } 2020 \\ \text { Org Code: } 70311 & \text { Charge Code: D4DK9 } \\ \text { B\&R Code: } & \text { EW3130010 } & \text { Total Pages: } 78\end{array}$

Key Words: Immobilized Low-Activity Waste (ILAW), National Environmental Policy Act (NEPA), State Environmental Policy Act (SEPA), Resource Conservation Recovery Act (RCRA).

Abstract: Permitting plan regarding NEPA, SEPA, RCRA and transportation standards, permitting strategy, cost and alternatives.

TRADEMARK DISCLAIMER. Reference herein to any specific commercial product, process, or service by trade name, trademark, manufacturer, or otherwise, does not necessarily constitute or imply its endorsement, recommendation, or favoring by the United States Government or any agency thereof or its contractors or subcontractors.

Printed in the United States of America. To obtain copies of this document, contact: Document Control Services, P.0. Box 950, Mailstop H6-08, Richland WA 99352, Phone (509) 372-2420;

Fax (509) 376-4989.
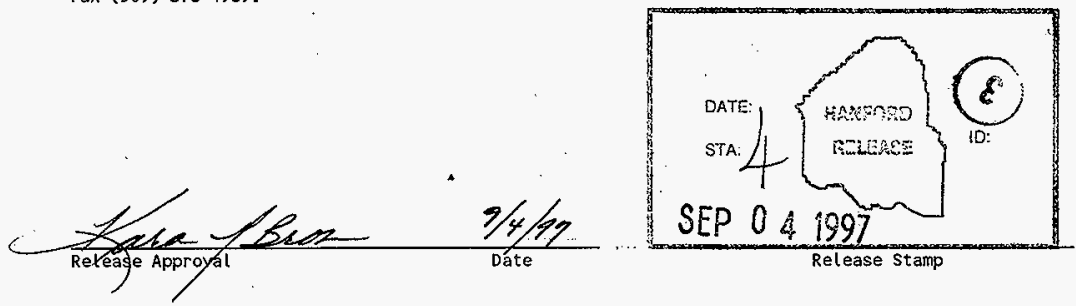

\section{Approved for Public Release}




\title{
Permitting Plan for the Immobilized Low-Activity Waste Project
}

\author{
M. L. Deffenbaugh \\ J. D. Guberski \\ C. J. Grando \\ V. L. Armstrong \\ Lockheed Martin Hanford Corposation
}

J. E. Mercado

Waste Management Federal Services, Northwest Operations

M. W. Cline

Waste Management Federal Services of Hanford, Inc.

Date Published

August 1997

Prepared for the U.S. Department of Energy

Assistant Secretary for Environmental Management 
HNF-SD-ENV-EE-003 Rev. 0

CONTENTS

1.0 INTRODUCTION . . . . . . . . . . . . . . 1-1

2.0 NATIONAL ENVIRONMENTAL POLICY ACT . . . . . . . . 2 2-1

2.1 INTRODUCTION . . . . . . . . 2-1

2.2 SUMMARY OF DATA AND/OR INFORMATION REQUIREMENTS ..... ${ }^{2-1}$

2.3 DISCUSSION OF ALTERNATIVES ............ $2-2$

2.4 RECOMMENDED NATIONAL ENVIRONMENTAL POLICY ACT STRATEGY $\cdots 2-2$

2.5 PRELIMINARY COST ESTIMATE . . . . . . . . . . 2-2

3.0 STATE ENVIRONMENTAL POLICY ACT . . . . . . . . . . . 3-1

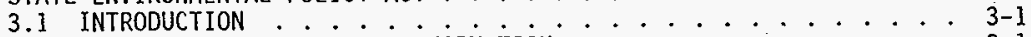

3.2 SUMMARY OF DATA AND $/ O R$ INFORMATION $\ldots \ldots . \ldots . \ldots$

3.3 DISCUSSION OF ALTERNATIVES ......... $3-1$

3.4 RECOMMENDED STATE ENVIRONMENTAL POLICY ACT STRATEGY . . . 3-2

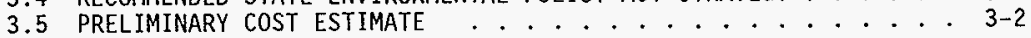

4.0 RESOURCE CONSERVATION AND RECOVERY ACT . . . . . . . . . . 4-1

4.1 INTRODUCTION . . . . . . . ............ 4-1

4.1.1 Notice of Intent ............... . . 4-1

4.1 .2 Part A...................... 4-2

4.1 .3 Part B ................ . . . . . . .

4.1 .4 Disposai Strategy . . . . . . . . . 4-2

4.2 SUMMARY OF DATA/INFORMATION REQUIREMENTS ........ 4-4

4.2.1 Notice of Intent and Part A . . . . . . . . 4-4

4.2 .2 Part B ............... 4-5

4.2.3 Variance from a Treatment Standard . . . . . 4-7

4.2.4 Rulemaking Petition ............ 4-7

4.2.5 Delisting Petition . . . . . . . . . . 4-7

4.3 DISCUSSION OF ALTERNATIVES ............ . . . . .

4.4. RECOMMENDED PERMITTING STRATEGY . . . . . . . . . . 4-12

4.5 PRELIMINARY COST ESTIMATE . . . . . . . . . . . . . . 4-12

5.0 THE ClEAN AIR ACT . . . . . . . . . . . . . . . . . 5-1

5.1 INTRODUCTION .................. . . . . . .

5.2 SUMMARY OF DATA/INFORMATION REQUIREMENTS . . . . . 5-1

5.3 DISCUSSION OF ALTERNATIVES ............. . . . $5-1$

5.4 RECOMMENDED PERMITTING STRATEGY . . . . . . . . . .

5.5 PRELIMINARY COST ESTIMATE . . . . . . . . . . . 5-1

6.0 TRANSPORTATION . . . . . . . . . . . ....... 6-1

6.1 INTRODUCTION . . . . . . . . . . . . 6-1

6.2 SUMMARY OF DATA/INFORMATION REQUIREMENTS ........ 6-1

6.3 DISCUSSION OF ALTERNATIVES ............... $6-1$

6.4 RECOMMENDED APPROVAL STRATEGY . . . . . . ..... 6-2

6.5 PREL IMINARY COST ESTIMATE . . . . . . . . . . . . 6-2

7.0 RADIATION PROTECTION STANDARDS/MONITORING .........

7.1 INTRODUCTION . . . . . . . . . . . . . . . .

7.2 SUMMARY OF DATA OF INFORMATION REQUIREMENTS ........ $7-1$

7.3 DISCUSSION OF ALTERNATIVES . . . . . . . . . . . 7-1

7.4 RECOMMENDED STRATEGY . . . . . . . . . . . . . 7-1 
HNF-SD-ENV-EE-003 Rev. 0

7.5 PRELIMINARY COST ESTIMATE . . . . . . . . . . . 7-2

8.0 REFERENCES .......................... . . . . . . . . .

APPENDIX A . LOW-LEVEL WASTE INTERIM STORAGE
PERMITTING PLAN COST AND SCHEDULE ............. A-1

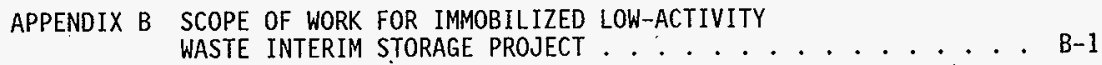


HNF-SD-ENV-EE-003 Rev. 0

\section{LIST OF TERMS}

$\begin{array}{ll}\text { AEA } & \text { Atomic Energy Act } \\ \text { ALARA } & \text { as low as reasonably achievable } \\ \text { CSB } & \text { Canister Storage Building } \\ \text { CFR } & \text { Code of Federal Regulations } \\ \text { CWC } & \text { Central Waste Complex } \\ \text { DOE } & \text { U.S. Department of Energy } \\ \text { DOE-RL } & \text { U.S. Department of Energy, Richland Operations office } \\ \text { DOT } & \text { U.S. Department of Transportation } \\ \text { DST } & \text { double-shell tank } \\ \text { ECOlogy } & \text { Washington State Department of Ecology } \\ \text { EIS } & \text { environmental impact statement } \\ \text { EPA } & \text { U.S. Environmental Protection Agency } \\ \text { FEIS } & \text { Final Environmental Impact Statement } \\ \text { HLW } & \text { high-level waste } \\ \text { IHLW } & \text { Immobilized High-Level Tank Waste } \\ \text { ILAW } & \text { Immobilized Low-Activity Tank Waste } \\ \text { LAW } & \text { low-activity waste } \\ \text { LLBG } & \text { low-level background } \\ \text { LLW } & \text { low-level waste } \\ \text { NEPA } & \text { National Environmental Policy Act of } 1969 \\ \text { NOD } & \text { Notice of Deficiency } \\ \text { NOI } & \text { Notice of Intent } \\ \text { NRC } & \text { Nuclear Regulatory Commission } \\ \text { PHMC } & \text { Project Hanford Management Contractor } \\ \text { RCRA } & \text { Resource Conservation and Recovery Act of 1976 } \\ \text { ROD } & \text { Record of Decision } \\ \text { SARP } & \text { Safety Analysis Report for Packaging } \\ \text { SEPA } & \text { State Environmental Policy Act of 1971 } \\ \text { SNF } & \text { Spent Nuclear Fuel } \\ \text { TPA } & \text { Tri-Party Agreement (Hanford Federal Facility Agreement } \\ \text { TSD } & \text { and Consent Order) } \\ \text { TWRS } & \text { treatment, storage, and/or disposal } \\ \text { WAC } & \text { Tank Waste Remediation Systems } \\ & \text { Washington Administrative Code } \\ & \end{array}$


HNF-SD-ENV-EE-003 ReV. 0

This page intentionaliy left blank. 
HNF-SD-ENV-EE-003 ReV. 0

\section{PERMITTING PLAN FOR THE IMMOBILIZED LOW-ACTIVITY WASTE PROJECT}

\subsection{INTRODUCTION}

This document addresses the environmental permitting requirements for the transportation and interim storage of the Immobilized Low-Activity Waste (ILAW) produced during Phase 1 of the Hanford Site privatization effort.

Tri-Party Agreement (TPA) Milestone M-90 establishes a new major milestone, and associated interim milestones and target dates, governing acquisition and/or modification of facilities necessary for: 1) interim storage and disposal of Tank Waste Remediation Systems (TWRS) immobilized low-activity tank waste (ILAW) and 2) interim storage of TWRS immobilized HLW (IHLW) and other canistered high-level waste forms.

Low-activity waste (LAW), law-level waste (LLW), and high-level waste (HLW) are defined by the "TWRS, Hanford Site, Richland, Washington, Final Environmental Impact Statement (EIS)" DOE/EIS-0189, August 1996 (TWRS, Final EIS). By definition, HLW requires permanent isolation in a deep geologic repository. Also by definition, LAW is "the waste that remains after separating from high-level waste as much of the radioactivity as is practicable that when solidified may be disposed of as LLW in a near-surface facility according to the NRC regulations."

It is planned to store/dispose of (ILAW) inside four empty vaults of the five that were originally constructed for the Group Program.

Additional disposal facilities will be constructed to accommodate immobilized LLW packages produced after the Grout Vaults are filled. The specifications for performance of the low-activity vitrified waste form have been established with strong consideration of risk to the public. The specifications for glass waste from performance are being closely coordinated with analysis of risk. RL has pursued discussions with the NRC for a determination of the classification of the Hanford Site's low-activity tank waste fraction. There is no known RL action to change law with respect to onsite disposal of waste.

An environmental requirements checklist and narrative titled "Environmental Requirements Checklist For The Immobilized Low-Activity Waste Interim Storage, Project W-465"; (interoffice memorandum \#70370-97-003), was developed to identify the permitting path forward for the (ILAW) project (See Appendix B). This permitting plan will follow the permitting logic developed in that check7ist. 
HNF-SD-ENV-EE-003 Rev. 0

This page intentionally left blank. 


\subsection{NATIONAL ENVIRONMENTAL. POLICY ACT}

The National Environmental Policy Act of 1969 (NEPA) (42 USC 4321, et seq.), was enacted to ensure that environmental matters are considered before federal actions are initiated that might affect the quality of the human environment. The DOE regulation, National Environmental Policy Act Implementing Procedures [10 Code of Federal Regulations (CFR) 1021], promulgated under NEPA was developed to conform with 40 CFR 1500-1508 regulations and to categorize the environmental impacts associated with various DOE proposals or actions.

\subsection{INTRODUCTION}

The proposed action to store LAW canisters by improving the existing grout vaults is a major action requiring appropriate NEPA documentation.

\subsection{SUMMARY OF DATA AND/OR INFORMATION REQUIREMENTS}

The types of information and data needed can be grouped into the following broad categories:

- Purpose and Need for Action

- Why action is needed now and how it relates to other actions.

- Alternatives Considered

- Do nothing different from current starage, pick a disposal method that does not require intermediate storage, use a different type or form of interim waste storage, or use a different location for interim storage.

- Environments and Resources Affected

- Geological, aquatic, atmospheric, biological, cultural, socioeconomic, terrestrial, visual, audio, and natural environments; transportation resources.

- Environmental Consequences

- Possibie consequences to environments listed above. Also, anticipated health affects from routine and non-routine operations, including accidents. Possibility of disproportionate impacts on minority group(s) must be identified.

- Statutory and Regulatory Requirements

- These relate to Resource Conservation and Recovery Act of 1976 (RCRA) and other permitting requirements addressed in other sections of this permitting plan. 
Preparation of appropriate NEPA documentation requires data on: natural, biological, or cultural resources used or impacted by the alternatives considered; socioeconomics of the region; land use, both current and future; visual resources impacted; noise and transportation impacts from construction, operation, and decommissioning; and hazardous or toxic substances used or potentially released into the environment.

\subsection{DISCUSSION OF ALTERNATIVES}

Three alternatives exist for NEPA documentation regarding the action to store and dispose LAW containers in the grout vaults:

1. Prepare an environmental impact statement (EIS).

2. Prepare an environmental assessment to determine if an EIS is needed - or if a finding of no significant impact is appropriate.

3. Identify that the action to be taken is covered by an existing EIS.

\subsection{RECOMMENDED NATIONAL ENVIRONMENTAL POLICY ACT STRATEGY}

Adhere to the U. S. Department of Energy's Record of Decision (ROD), [62 FR 8693] for the Tank Waste Remediation System. The ROD was based upon the Final Environmental Impact Statement for the Tank Waste Remediation System, DOE/EISO189F (DOE 1996b), co-authored by the U.S. Department of Energy and the Washington State Department of Ecology (Ecology).

The "Phased Implementation Alternative," was identified in the final EIS as the preferred alternative. The pertinent items listed within the ROD are:

- Constructing demonstration-scale facilities to produce vitrified low activity waste

- Vitrifying the high-level waste stream and the low-activity waste stream

- Placing the immobilized low-activity waste in containers and placing the containers in onsite, near-surface, disposal facilities

- Transporting the low- and high-activity wastes to onsite interim storage facilities.

\subsection{PRELIMINARY COST ESTIMATE}

(See Appendix A) 
HNF-SD-ENV-EE-003 Rev. 0

\subsection{STATE ENVIRONMENTAL POLICY ACT}

The State Environmental Policy Act of 1971 (SEPA) (Chapter 43.21C Revised Code of Washington) legislation is the Washington State equivalent of NEPA, and requires evaluation of environmental impacts associated with a project or an agency action before approval of the project or action is granted. The SEPA rules, Washington Administrative Code (WAC) Chapter 197-11 (WAC 197-11), are the implementing regulations.

\subsection{INTRODUCTION}

The normal method of addressing the SEPA requirements is to complete a SEPA checklist that provides the information necessary for the appropriate State agency to make a threshold determination on the significance of the proposed action. If the proposed action is categorically exempt or non-significant, further action under SEPA is not required. If the proposed action is significant, preparation of an environmental impact statement is required. An option exists for adoption of an existing document(s) (for example, a NEPA EIS) to fulfil the agency's responsibilities.

\subsection{SUMMARY OF DATA AND/OR INFORMATION}

The types of data and information needed are those discussed in Section 2.2 regarding the NEPA process.

\subsection{DISCUSSION OF ALTERNATIVES}

Three alternatives exist for compliance with SEPA:

1. Submit a SEPA checklist in conjunction with an application for permit(s) needed (for example, air, RCRA, building) and let the agency determine if an environmental impact statement is required.

2. Submit a letter to, or provide a briefing to, appropriate regulatory agencies (Ecology is normally the lead agency for TWRS activities) stating that the U.S. Department of Energy, Richland Operations Office (DOE-RL) believes an environmental impact statement is required.

3. Submit a letter to, or provide a briefing to, appropriate regulatory agencies (Ecology is normally the lead agency for TWRS activities) stating that DOE-RL believes that existing environmental documentation provided to or prepared by Washington State agencies, and issuance of permits by those agencies, cover this action. 


$$
\text { HNF-SD-ENV-EE-003 ReV. } 0
$$

\subsection{RECOMMENDED STATE ENVIRONHENTAL POLICY ACT STRATEGY}

The recommended approach is to inform Ecology that the Tank Waste Remediation Systems/Final Environmental Impact Statement (TWRS/FEIS) (DOE 1996b), and issuance of permits necessary for use of the existing grout vaults cover this action. This could be included in the notice of intent for RCRA permitting (See Section 4.3).

\subsection{PRELIMINARY COST ESTIMATE}

(See Appendix A) 
HNF-SD-ENV-EE-003 ReV. 0

\subsection{RESOURCE CONSERVATION AND RECOVERY ACT}

RCRA was enacted as a comprehensive national program to mandate that hazardous waste will be treated, stored, and disposed of so as to minimize the present and future threat to human health and the environment. In the State of Washington, the dangerous waste regulations (WAC 173-303) are the implementing regulations.

\subsection{INTRODUCTION}

The ILAW project will provide interim storage and disposal for ILAW waste that has been treated by vitrification. The treatment, storage, and/or disposal (TSD) unit(s) that will be used to manage the ILAW will need to be permitted per WAC 173-303 to accommodate this activity.

A portion of the Hanford Facility application for a TSD unit permit consists of three collective submittals. Each submittal consists of various levels of detailed information concerning the TSD Unit. The three submittals are the Notice of Intent (NOI), the unit-specific form 3 portion of the Hanford Facility Part A permit application (Part A), and the unit-specific portion of the Hanford Facility Part B permit application (Part B).

The dangerous waste regulations (WAC 173-303) apply to all facilities within Washington State that treat, store, and/or dispose of dangerous waste. These regulations are equivalent to, or more stringent than, the federal hazardous waste regulations. Under the dangerous waste program, all TSD units on the Hanford Facility must obtain a permit. Facilities that were in existence on November 19, 1980, were granted an interim status permit with the submittal of a Part A identifying the intent to treat, store, and/or dispose of dangerous waste. Interim status ends after final administrative disposition of the Part B documentation is completed, and a final status permit is granted or denied.

Refer to Appendix A for the RCRA ILAW permitting schedule.

\subsubsection{Notice of Intent}

An NOI is required for expansion of the Hanford Facility, an existing facility. Expansion includes enlargement of 7 and surface area; the addition of new dangerous waste processes, or an increase in overall design capacity. The NOI contains preliminary information concerning the TSD unit expansion. The NOI requires a general process description, operating capacities, waste type, a topographic map, a statement of environmental conditions, and could include a SEPA environmental checklist.

In accordance with WAC 173-303-281, the NOI must be submitted to the public (public reading rooms), Ecology, and the EPA, Region 10. A public notification is published in a local daily newspaper for 14 consecutive days. The NOI process normally requires approximately 11 months to complete and submit. 
HNF-SD-ENV-EE-003 Rev. 0

\subsubsection{Part A}

The Part A includes process design capacity, process description, dangerous waste numbers and estimated annual quantity, description of dangerous waste, facility diagrams, photographs, geographic location, facility owner, and operator/co-operator certification. The Part $A$ is submitted no earijer than 150 days following submittal of the NOI to Ecology and the public. The preparation process requires approximately 5 months to complete; including DOE-RL/Project Hanford Management Contractor (PHMC) review and certification.

\subsubsection{Part B}

The Part B provides detailed descriptions of the design, operation and maintenance, training, contingency planning, closure, and other relevant information concerning the TSD Unit.

The Part $B$ is evaluated by the regulating agencies for completeness and technical adequacy. The latter includes plausibility, general detail of plans and procedures, and protection of human health and the environment. For any item deemed incomplete or technically inadequate, Ecology issues a notice of deficiency (NOD) to the applicant. Resolution of NODs and subsequent modification of the Part B permit application is through an informal workshop process that involves the DOE-RL, PHMC, and Ecology.

When satisfied, Ecology prepares a draft permit modification to incorporate the unit into the Hanford Facility RCRA Permit. This draft permit modification is published for public and interagency review. Upon completion of the public review period, significant public comments are factored into the final status permit modification issued by Ecology. Generally, preparation of a unit-specific Part B permit application requires approximately 14 months through the first certification cycle, and the total duration may last approximately 3 to 6 years.

Interim status expansion may be requested from Ecology and the U.S. EPA. Once the revised Part A, form 3 and NOI are submitted, construction can proceed if Ecology and EPA grant interim status expansion under the Hanford Facility Part A Permit Application.

\subsubsection{Disposal Strategy}

Vitrification was identified by the U.S. Environmental Protection Agency (EPA) as the "specified method" for the corrosive and toxic characteristic heavy metals associated with high level mixed waste as promulgated in the Federal Register on June 1, 1990. This provision does not address the treatment of low activity mixed waste by vitrification. The waste stored in the doubleshell tank system remains subject to the concentration based treatment standards. Per the current regulations, the vitrified ILAW must be sampled after treatment. To perform Toxicity Characteristic Leaching Procedure on this sample, the sample must be size reduced and tested, demonstrating that the extract concentrations do not exceed the concentration based treatment standards. In addition to the waste numbers identified for the DST System, the vitrified ILAW must also be analyzed for the underlying hazardous 
constituents identified in 40 CFR 268. Until the ILAW can meet the treatment standards, it can not be allowed to be disposed of in a Subtitle C (RCRA) landfi11. There are several options available for achieving authorization to dispose of the vitrified ILAW. These options are discussed below:

- No action. This option requires the vitrified ILAW to be ground to a powder and subjected to sampling and analysis. If the resulting vitrified ILAW meets the concentration based treatment standards, the vitrified ILAW may be placed in a Subtitle $C$ landfill. The vitrified ILAW cannot be disposed of in a Subtit7e 0 Landfill because the treated waste will still be a listed waste. If the resulting leachate does not meet the concentration based treatment standards, the waste will need to be treated again, or a variance from the applicable treatment standards will have to be pursued.

- Submit a rulemaking petition to gain approval of the vitrification process as the "specified method" for all waste numbers associated with DST System waste. When approved by the EPA, the vitrified ILAW could be disposed directly to a Subtitle C landfill following treatment without testing.

- In addition to gaining approval to dispose of vitrified ILAW in a Subtitle $C$ landfill, a delisting petition could be pursued to allow disposal in a landfill that complies with Subtitle D and/or Atomic Energy Act (AEA) requirements.

Because the process for obtaining these regulatory modifications is lengthy and dependent on actions to be taken by the private contractors, storage capacity must be established while authorization to dispose of the vitrified ILAW is pursued. In order to provide the greatest likelihood of success for storing ILAW on the schedule outlined in the Tri-Party Agreement, TWRS Environmental is proposing to obtain a RCRA permit for storage of ILAW while concurrently working with the EPA and Ecology to obtain any necessary regulatory modifications to support disposal of the ILAW. The process identified follows regulations set forth by EPA. EPA is the primary regulator for these petitions, however Ecology has similar regulations (WAC 173-303-072 \& -910) which also must be followed. The following sections discuss potential disposal regulatory modifications that may be elected by the PHMC or imposed by the regulators. The administrative processes are similar but the resultant options differ significantly.

\subsubsection{Variance from a Treatment Standard}

A variance from a treatment standard could be pursued if the resultant waste form does not meet concentration based standards published in the 40 CFR 268 . The administrative process to petition the EPA to amend 40. CFR Part 268 to obtain a variance from a treatment standard is contained in 40 CFR 260.20. The administrative process includes: a petition by DOE of EPA to modify or amend 40 CFR 268; EPA evaluation of the petition; EPA publication of its tentative decision in the Federal Register, and issuance of a request for. public comment; EPA evaluation of the public comments; and EPA arrival at a final decision. EPA will publish its final decision in the Federal Register. 
HNF-SD-ENV-EE-003 Rev. 0

\subsubsection{Rulemaking Petition}

A rulemaking petition could be pursued to identify vitrification as the specified method for treatment of Hanford Site tank waste. If approved, Hanford Site tank waste once treated per the specified method would not require further testing and could be disposed of to a Subtitle ' $C$ ' 1 andfill. The administrative process to petition the EPA and amend 40 CFR Part 268 to obtain approval of the vitrification process as the "specified method" for ILAW is contained in 40 CFR 260.20. The administrative process includes: a petition by DOE of EPA to modify or amend 40 CFR 268; EPA evaluation of the petition; EPA publication of its tentative decision in the Federal Register, and issuance of a request for public comment; EPA evaluation of the public comments; and EPA arrival at a final decision. EPA will publish its final decision in the Federal Register.

\subsubsection{Delisting Petition}

A delisting petition could be pursued to allow disposal in a Subtitle 'D' or AEA (non-hazardous, radioactive) landfil1. The administrative process to petition the EPA to amend 40 CFR Part 261 to exclude a waste (that is, delisting) is contained in 40 CFR 260.20 and 40 CFR 260.22. The administrative process includes: a petition by DOE of EPA to modify or amend 40 CFR 261; EPA evaluation of the petition; EPA publication of its tentative decision in the Federal Register, and issuance of a request for public comment; EPA evaluation of the public comments; and EPA arrival at a final decision. EPA publishes its final decision in the Federal Register and, if the petition is approved, will issue a regulatory amendment. Successful petitions to amend $40 \mathrm{CFR} 261$ can be found in 40 CFR 261, Appendix IX, Table 1 .

\subsection{SUMMARY OF DATA/INFORMATION REQUIREMENTS}

Following is a summary of the information required for the RCRA permit documentation under WAC 173-303, "Dangerous Waste Regulations," and the information required for the various petitions under 40 CFR 260 .

\subsubsection{Notice of Intent and Part $A$}

The following information is required under WAC 173-303-281, -282 and -805 when submitting an NOI for expansion under interim status:

- TSD unit-description

- Explanation of expansion

- Siting criteria

- 10-year summary of compliance violations at the Hanford Facility

- Demonstrated need for expansion 
HNF-SD-ENV-EE-003 ReV. 0

- Comparison of proposed expansion to overall Hanford Facility capacity

- A SEPA environmental checklist

- 150-day public review of NOI prior to filing the Part $A$, form 3

- File a Part A Permit Application, form 3, with Ecology after public review period ends for NOI.

\subsubsection{Part B}

Following are general requirements for the Part $B$. These requirements are not considered all inclusive. The information required in the Part $B$ can be found in WAC $173-303-806$.

- A general description of the facility

- Chemical, biological, and physical analyses of the dangerous waste and hazardous debris to be handled at the unit. At a minimum, these analyses must contain all the information which must be known to treat, store, or dispose of the wastes properly in accordance with WAC 173-303-600.

- A copy of the waste anajysis plan required by WAC 173-303-300(5)

- A description of security procedures and equipment required by WAC 173-303-310, or a justification demonstrating the reasons for requesting a waiver of this requirement

- A copy of the general inspection schedule required by WAC 173-303$320(2), 173-303-630(6)$, and $173-303-665(4)$

- A description of the procedures used to comply with the preparedness and prevention requirements of WAC 173-303-340, or a justification of any request for a waiver(s) from these requirements

- A copy of the contingency plan required by WAC 173-303-350

- A description of the procedures, structures, or equipment used at the facility to:

- Prevent hazards and contain spills in unloading/loading operations

- Prevent runoff from dangerous waste handling areas to other areas of the unit or environment, or to prevent flooding

- Prevent contamination of water supplies

- Mitigate effects of equipment failure and power outages

- Prevent undue exposure of personnel to dangerous waste 
- Prevent releases to the atmosphere.

- Vehicular traffic pattern, estimated volume, and control

- Seismic risk consideration. The owner or operator must identify the seismic risk zone in which the facility is intended to be located. It must be demonstrated that the facility is designed to resist seismic ground motion and that the design is sufficient to withstand the maximum horizontal acceleration of a design earthquake specified in the demonstration.

- An outline of both the introductory and continuing training programs that prepare persons to operate or maintain the TSD facility in a safe manner as required to demonstrate compliance with WAC 173-303330. A brief description of how training will be designed to meet actual job tasks in accordance with the requirements in WAC 173-303$330(1)(d)$.

- A copy of the closure plan required by WAC 173-303-610(3), 173-303$630(10)$, and $173-303-665(6)$

- Closure estimate (without financial assurance)

- A topographic map meeting all applicable requirements in WAC 173$303-806(4)$ (a) (xvi $i j)$.

\subsubsection{Specific Container Requirements}

- Address the requirements of WAC 173-303-630 for container management, including the following:

- A description of the containment system to demonstrate compliance with WAC 173-303-630(7). Show at least:

- Basic design parameters, dimensions, and materials of construction, including allowance for a 25-year, 24-hour storm

- How the design promotes positive drainage control or how containers are kept from contact with standing liquids in the containment system

- Capacity of the containment system relative to the volume of the Targest container to be stored

- Provisions for preventing or managing run-on

- How accumulated liquids can be analyzed and removed to prevent overflow

- A description of the building or other protective covering for extremely hazardous waste containers. 
- For storage areas that store containers holding wastes that do not contain free liquids, a demonstration of compliance with WAC 173-303-630(7)(c), including:

- Test procedures and results or other documentation or information to show that the wastes do not contain free liquids

- A description of how the storage area is designed or operated to drain and remove liquids or how containers are kept from contact with standing liquids

- A description of procedures for labeling containers.

\subsubsection{Specific Landfill Requirements}

- Address the requirements of WAC 173-303-665 for 1 andfi11s, including the following:

- The design and operating requirements for the 1 andfill

- A description of the inspection plan to be applied during operation

- A description of the leachate collection system

- A response action plan that identifies actions to be taken. when the flow rate into the leak detection system exceeds the defined action leakage rate.

- The control mechanisms in place to address run-on and run-off.

\subsubsection{Variance from a Treatment Standard}

In order to be successful, the petitioner must provide information required by 40 CFR 268.44(a) or (b) and applicable portions of 40 CFR 260.20. Similarly, WAC 173-303-072 and -910 also must be satisfied.

\subsubsection{Rulemaking Petition}

In order to be successful, the petitioner must provide information required by 40 CFR 260.20 and WAC 173-303-072 and -910.

\subsubsection{Delisting Petition}

In order to be successful, the petitioner must provide the following information:

- Demonstrate to the satisfaction of the EPA and Ecology that the ILAW produced by the private vendor does not meet any of the criteria under which the waste was listed as a hazardous or acutely hazardous waste (40 CFR 260.22(a)). The demonstration must be made with respect to the waste mixture as a whole, and must apply to a 
HNF-SD-ENV-EE-003 ReV. 0

specific waste generated at a specific facility and stored in a specific unit (40 CFR 260.22(b)). See also WAC 173-303-072 and -910 .

- Conduct analyses not only for those constituents for which the listed waste contained in the mixture was 1 isted, but also for other factors (including additional constituents) that could cause the waste mixture to be a hazardous waste ( 40 CFR 260.22(b)).

- Provide extensive information regarding the process that generated the waste (40 CFR 260.22(i)).

- Provide extensive information regarding the laboratory and analytical methods used (40 CFR 260.22(i)).

The EPA and Ecology can request any additional information which they may reasonably require in order to evaluate the petition.

The unique data required by the PHMC for the petition are highly dependent on the information that can be obtained from the private contractors, who are required by contract to comply with the $T$ and disposal restrictions

( 40 CFR 268). The analytical data and testing of vitrified ILAW required for this delisting petition appear to be redundant to these requirements.

Definitive estimates of scope, schedule, and resources cannot be developed until these redundancies are explored. Significant cost and schedule savings can occur if data developed by the private contractors, used to demonstrate compliance with the land disposal restrictions, can be used for the delisting petition.

\subsection{DISCUSSION OF ALTERNATIVES}

The alternatives for permitting ILAW storage and disposal are discussed below. These alternatives describe the permit options as related to current or new facility permit applications. The probability of success (High, Medium, Low) will follow each listed alternative. The alternatives discussed are 1) establishing a new TSD Unit, 2) expansion of the Grout Treatment Facility TSD Unit, 3) expansion of the Low-Level Burial Grounds (LLBG) TSD Unit, 4) expansion of the Double-Shell Tank (DST) System TSD Unit, and 5) expansion of the Central Waste Complex (CWC) TSD Unit.

1. Establishing A New TSD Unit - Submit an NOI for expansion under interim status (adding a new unit to the Hanford Facility) and submit a new Part A, form 3. This alternative will estabi ish the existing Grout Vaults as a separate interim status TSD unit that is permitted for container storage and landfill disposal. This proposal will require modification of the existing Grout Treatment Facility Part A Permit Application, form 3, to remove reference to the existing vaults. Negotiate with Ecology for a date for finalization of the unit-specific portion of the Part B permit application. Proceed with petitions for regulatory modifications necessary to accommodate ILAW disposal. (High) 
Assumptions :

a) An NOI will be submitted to increase the Hanford Facility container storage and disposal capacity.

b) New Part A, form 3, and unit-specific portion of the Part B permit applications will be written and submitted.

c) A modification of the Grout Treatment Facility Part A, form 3, will be submitted to remove the surface.impoundment process code and storage capacities currently identified for the existing grout vaults. Closure activities could be scheduled to close out the remaining Grout Treatment Facility if appropriate.

d) The Hanford Facility RCRA permit modification schedule will be modified to include the new TSD permitting schedule. DOE/RL-91-28, Hanford Faci7ity Dangerous Waste Permit Application, General Information (DOE-RL 1991), will also require modification.

2. Expansion of the Grout Treatment Facility - Submit an NOI for expansion under interim status and submit a revised Grout Treatment Facility Part A Permit Application, form 3, to change the existing vaults to container storage and landfill disposal. This alternative will establish the existing Grout Vaults as an interim status TSD unit that is permitted for container storage and landfill disposal. Negotiate with Ecology for a date for finalization of the unit-specific Part B permit application. Proceed with petitions for regulatory modifications necessary to accommodate ILAW disposal. (Medium)

Assumptions:

a) The Grout Treatment Facility Part A, form 3, will be modified by changing the surface impoundment storage and landfill capacity/process to container storage and landfill disposal capacity/process. Dangerous waste numbers may be affected.

b) An NOI will be submitted to change the process code from a surface impoundment to a container storage area. Associated container storage and landfill disposal capacities will be established for the vaults.

c) The Part B permit application will be revised to reflect the new process/operation at the vaults.

d) The Hanford Facility RCRA permit will be modified to reflect the change in mission for the vaults. DOE/RL-91-28, Hanford Facility Dangerous Waste Permit Application, Genera? Information (DOE-RL 1991), will also require modification. 
3. Expansion of the LLBG - Submit an NOI for expansion under interim status and submit a revised LLBG Part A Permit Application, form 3 , to add the existing vaults as additional container storage and landfill disposal capacity. This alternative will establish the existing Grout Vaults as part of an interim status TSD unit that is permitted for container storage and landfill disposal (the LLBG will become incorporated into the Hanford Facility RCRA permit in 1997, at which point a permit modification will be required for this change). Proceed with petitions for regulatory modifications necessary to accommodate ILAW disposal. (Low)

Assumptions :

a) The LLBG Part $A$, form 3, will be modified to include container storage and landfill disposal at the vaults as an additional waste management process for the LLBG system. Dangerous waste numbers may be affected.

b) The Grout Treatment Facility Part A, form 3, will require revision to remove the existing vaults.

c) An NOI will be submitted to expand the LLBG to include container storage and landfill disposal at the Grout vaults. Associated container storage and disposal capacities will be established for the vaults.

d) The Part B permit application will be revised to reflect the new process/operation at the vaults.

e) The Hanford Facility RCRA permit will be modified to reflect the change in mission for the vaults. DOE/RL-91-28, Hanford Facility Dangerous Waste Permit Application, General

Information (DOE-RL 1991), will also require modification.

4. Expansion of the DST System - Submit an NOI for expansion under interim status and submit a revised DST System Part A Permit Application, form 3 , to add the existing vaults as additional container storage and landfill disposal capacity. This alternative will establish the existing Grout Vaults as part of an interim status TSO unit that is permitted for container storage and landfill disposal (the DST System will become incorporated into the Hanford Facility RCRA permit in 1999, at which point a permit modification will be required). Proceed with petitions for regulatory modifications necessary to accommodate ILAW disposal. (Low)

Assumptions:

a) The DST Part A, form 3, will be modified to include container storage and landfill disposal at the existing vaults as an additional waste management process for the DST System. Dangerous waste numbers may be affected. 
b) The Grout Treatment Facility Part $A$, form 3, will require revision to remove the existing vaults currently permitted within the Grout Treatment Facility.

c) An NOI will be submitted to expand the DST system to include container storage and 1 andfill disposal at the existing Grout vaults. Associated container storage and landfill disposal capacities will be established for the vaults.

d) The Part $B$ permit application will be revised to reflect the new process/operation at the vaults.

e) The Hanford Facility RCRA permit will be modified to reflect the change in mission for the vaults. DOE/RL-91-28, Hanford Facility Dangerous Waste Permit Application, Genera?

Information (DOE-RL 1991), will also require modification.

5. Expansion of the CWC - Submit an NOI for expansion under interim status and submit a revised CWC Part A Permit Application, form 3, to add the existing vaults as additional container storage and landfill disposal capacity. This alternative will establish the existing Grout Vaults as part of an interim status TSD unit that is permitted for container storage and landfill disposal (the CWC will become incorporated into the Hanford Facility RCRA permit in 1998, at which point a permit modification will be required for this change). Proceed with petitions for regulatory modifications necessary to accommodate ILAW disposa1. (LOW)

Assumptions:

a) The CWC Part A, form 3, will be modified to include container storage and 1 andfill disposal at the vaults as an additional waste management process for CWC. Dangerous waste numbers may be affected.

b) The Grout Treatment Facility Part $A$, form 3 , will require revision to remove the existing vaults currently permitted within the Grout Treatment Facility.

c) An NOI will be submitted to expand CWC to include container storage and landfill disposal at the Grout vaults. Associated container storage and 1 andfill disposal capacities will be established for the vaults.

d) The Part $B$ permit application will be revised to reflect the new process/operation at the vaults.

e) The Hanford Facility RCRA permit will be modified to reflect the change in mission for the vaults. DOE/RL-91-28, Hanford Facility Dangerous Waste Permit Application, General

Information (DOE-RL 1991), will also require modification. 


\subsection{RECOMMENDED PERMITTING STRATEGY}

The desired path is to establish the existing Grout vaults as a separate interim status container storage and landfill disposal unit (alternative \#1). This will allow for the indefinite storage of vitrified ILAW until a regulatory pathway is established for disposal of the vitrified waste matrix. Negotiations could then be conducted with Ecology to define the date for finalization of the associated Part B. It needs to be understood that Ecology could require a final status permit for the vaults prior to initiation of efforts required to ready the vaults for container management. This issue is subject to negotiation with Ecology and will most likely be raised during the NOI/Part A revision process.

Concurrent with this effort, proceed with a rulemaking petition for establishment of vitrification of Hanford Facility DST System mixed waste as the "specified technology." This will allow the future disposal of the ILAW without any sampling being required to confirm compliance with treatment standards: A delisting petition could also be pursued that may allow the ILAW to exit RCRA, allowing disposal in a Subtitle D or AEA landfill.

\subsection{PRELIMINARY COST ESTIMATE}

(See Appendix A). 
HNF-SD-ENV-EE-003 ReV. 0

\subsection{THE CLEAN AIR ACT}

The Federal Clean Air Act of 1970 (42 USC 7401 et seq.) was enacted in 1970 , amended in 1977, and overhauled and expanded in 1990.

\subsection{INTRODUCTION}

Immobilized low activity waste is to be produced by privately owned lowactivity waste immobilization facilities as part of the privatization effort. Low Level Waste Immobilization Facility as part of the privatization effort to provide safe processing of Hanford Tank wastes. The initially produced ILAW is to be stored in the interior of four former grout vaults, buildings 218-E$16-102,-103,-104$, and -105 , until final onsite disposal can be accomplished. A detailed review of the facility design, the storage process, the physical form of the emission sources, and the regulatory requirements concluded that interim storage of the ILAW in these grout vaults does not constitute a source of regulated emissions to the atmosphere. The ILAW products will be sealed in metal containers. The closure system will be leak tight as defined by ANSI Standard N14.5. Each container is to be decontaminated and surveyed before being transferred to the grout vaults for interim storage. Removable surface contamination will not exceed the limits described in 49 CFR 173.443(a).

Because these containment methods are used, no requirement exists for permitting the Grout Vaults under federal/state regulations.

\subsection{SUMMARY OF DATA/INFORMATION REQUIREMENTS}

This conclusion was based on a detailed review of the project design criteria and State and federal regulatory requirements.

\subsection{DISCUSSION OF ALTERNATIVES}

No a]ternatives are needed.

\subsection{RECOMMENDED PERMITTING STRATEGY}

Confirmation from the Washington State Departments of Health and Ecology that the hermetically sealed canisters/containers do not constitute a source of regulated emissions will be obtained from each State agency in writing.

\subsection{PRELIMINARY COST ESTIMATE}

(See Appendix A) 
HNF-SD-ENV-EE-003 Rev. 0

This page intentionally left blank. 


\subsection{TRANSPORTATION}

The transportation of radioactive materials within Hanford Site boundaries in areas that are not accessible to the public is not currently subject to U.S. Department of Transportation (DOT) regulation. Transportation and packaging operations are authorized and controlled by contractor-approved procedures and safety evaluations.

\subsection{INTRODUCTION}

The mechanism by which the transportation and packaging of radioactive materials is approved under the current PHMC program involves the application of requirements similar to those imposed by DOT and the Nuclear Reguiatory Commission (NRC) for the transportation of these materials in the public domain. The design of the packaging is a primary element in identifying the applicable requirements and the extent to which the shipments of ILAW to the storage site must be controlled. Packaging systems which afford the greatest degree of protection for the contents require the lowest degree of operational control.

In order that the applicable requirements and approvals may be fully identified, the packaging design must be fully defined. The maximum intended payload must also be defined. Other parameters that should be established before the necessary approvals can be obtained include the shipment route and frequency.

\subsection{SUMMARY OF DATA/INFORMATION REQUIREMENTS}

The primary information required in order. to proceed with authorization of the packaging system and the shipment campaign is as follows:

- Detailed design of the packaging system

- Description of the transportation system

- Detailed description of the bounding payload, including radioisotopic content, chemical constituents, physical properties, thermal properties, and mechanical properties

- Transport mode (highway or rail) and route

- Number and frequency of shipments.

\subsection{DISCUSSION OF ALTERNATIVES}

The basic alternatives for approval of the transportation aspects of the HLW Interim Storage Project are limited. One approach is to fully comply. with DOT and NRC regulations that govern the transportation of Type $B$ quantities of radioactive material. The remaining alternative is to design and operate a packaging and transportation system under the PHMC onsite Transportation 
HNF-SD-ENV-EE-003 Rev. 0

Safety Program as defined in WHC-CM-2-14, Hazardous Material Packaging and Shipping.

The first alternative, full regulatory compliance for offsite shipping, requires the use of a certified packaging system. Unless a currently certified system is identified and is usable for this campaign, the selection of this alternative typically requires an effort of two to five years to obtain certification of the packaging design, along with significant cost to execute the process. Another difficulty that would be encountered if this alternative were selected is the necessity to fully characterize the material being shipped, a process that may not be completed until the production of the payload is well underway. The advantages of this approach include the possession of a well-established pedigree from an independent regulatory agnecy which is obtained through a defined process. This approach is clearly conservative from a safety perspective.

The second alternative, approval under the onsite transportation safety program, is more flexible and can take credit for safety aspects of the operation that do not contribute to the evaluations performed in support of the first alternative. The flexibility of this alternative lies in the safety criteria, which are based on potential dose consequences corresponding to accident frequencies. The advantages of this alternative include the use of less expensive packaging systems that are less cumbersome to handle. The onsite packaging and transportation procedures can be developed to apply as low as reasonably achievable (ALARA) principles in a manner not permitted by the first alternative. A disadvantage of this approach is that the packaging system would not be approved for shipment offsite to a final storage location.

\subsection{RECOMMENDED APPROVAL STRATEGY}

The recommended approval strategy for the packaging and transportation system is to conduct the design and safety evaluations within the onsite transportation safety program as described in WHC-CM-2-14, taking full advantage of the flexibility and cost efficiency provided by this approach. The packaging design and safety evaluations should be conducted in parallel.

\subsection{PRELIMINARY COST ESTIMATE}

For the recommended alternative, a preliminary cost estimate of $\$ 250,000$ has been developed for the activities associated with performing the safety evaluations and preparing an onsite Safety Analysis Report for Packaging (SARP). It is assumed that the actual packaging design effort will be funded separately from this process. The safety evaluations depend heavily on the payload definition, so if the bounding payload changes after the analysis is initiated, then the cost may be higher.

The other alternative considered, certified packaging, has a corresponding estimated cost of $\$ 2,000,000$. (See Appendix A.) 
HNF-SD-ENV-EE-003 ReV. 0

\subsection{RADIATION PROTECTION STANDARDS/MONITORING}

\subsection{INTRODUCTION}

DOE Order 5400.1, General Environmental Protection Program, and DOE Order 5400.5, Radiation Protection of the Public and the Environment, requires that monitoring be performed to determine the impact on the environment from activities that involve potential emission of radionuclides.

\subsection{SUMMARY OF DATA OF INFORMATION REQUIREMENTS}

Both DOE orders require that baseline data be obtained prior to the start of a project, and that periodic monitoring be performed to determine if the environment is being affected. The baseline data required include:

- Background radiation levels at the project site and in surrounding areas, including on-site and off-site.

- Radionuclides present in flora, fauna, soil, wildlife, water, vadoze and ground water, agriculture products and animals, and in some circumstances, members of the public.

\subsection{DISCUSSION OF ALTERNATIVES}

The three alternatives available for this project are: 1) gather the required information specifically for this project; 2) use information gathered by the grout project and routine monitoring of the Hanford Site; and 3) use routine monitoring data for the Hanford Site supplemented by project-specific data related to the location of the grout vaults.

Alternative 1, gathering the data specificaliy for this project would duplicate a considerable amount of monitoring work that is routinely performed regarding the Hanford Site and facilities. Also, for much of the preferred 2year baseline period the privatization project would be gathering similar data in an area that surrounds the grout vaults. Alternative 1 is judged to the most expensive alternative.

Alternative 2, makes use of existing data for the baseline and limits this project to ongoing monitoring. The ongoing monitoring can be accomplished by use of site programs and the specific monitoring established for the privatization project. It is expected that privatization monitoring data will be available, either as public records or as part of the privatization contract.

Alternative 3 , makes use of existing data, from both the Site and privatization project, supplemented by data specific to storage of Immobilized Low Activity Waste.

\subsection{RECOMMENDED STRATEGY}

Eliminate alternative 1, gather baseline [characterization] data in conjunction with the privatization project, and make a decision later between alternative 2 and 3 for pre-operational, operational, and post operational 
monitoring. It is further recommended that the baseline data be gathered by being an active participant in developing [DRAFT] HNF-SD-TWR-EV-001, TWRS Phase I Privatization Site Environmental Baseline and Characterization Plan. This approach also enables DOE to determine what monitoring is needed to identify that effluents, particularly any that enter the soil, come from a particular facility.

The baseline data collection can best be accomplished by funding an appropriate share of the cultural and biological walk through of the privatization site, development of a project specific data quality objective, and development of privatization characterization plan.

\subsection{PRELIMINARY COST ESTIMATE}

Culture and Ecological baseline - $\$ 10,000$ funding of work to be performed by site infrastructure project. Preliminary work Feb-April 1998, with final FebApril 1999. Schedule controlled by nesting season.

Data Quality Objective - $\$ 40,000$ to prepare a data quality objective document. Recommend that work be done first quarter of FY 98 as it will help define what environmental monitoring is storage related and what is disposal related. Must be completed before end of CY 98 to support 2-year baseline data collection.

- $\$ 10,000$ to revise the existing data quality objective to address pre-operational, operational, and post-operational monitoring. FY 2000 first quarter.

Data Collection - $\$ 40,000$ funding of work to characterize the TWRS Phase I demonstration site during FY 99 and FY 2000. (See Appendix A.) 


\subsection{REFERENCES}

10 CFR 1021, 1992, "Compliance with the National Environmental Policy Act," Code of Federal Regulations, as amended.

40 CFR 260, 1980, "Hazardous Waste Management System: General," Code of Federal Regulations, as amended.

40 CFR 261, 1980, "Identification and Listing of Hazardous Waste," Code of Federal Regulations, as amended.

40 CFR 268, 1986, "Land Disposal Restrictions," Code of Federal Regulations, as amended.

62 FR 8692 , 1996, "U.S. Department of Energy Record of Decision for the Tank Waste Remediation System, Hanford Site, Richland, Washington, "Federal Register, Vol. 62, pp. 8692-8704, (February 26):

DOE, 1988, General Environmental Protection Program, DOE Order 5400.1, U.S. Department of Energy, Washington, D.C.

DOE, 1990, Radiation Protection of the Public and the Environment, DOE Order 5400.5 , U.S. Department of Energy, Washington, D.C.

DOE, 1991, General Information Portion, D0E/RL-91-28, U.S. Department of Energy, Richland Operations Office, Richland, Washington.

DOE, 1996a, Final Environmental Impact Statement: Management of Spent Nuclear Fuel from the K-Basins at the Hanford Site, Richland, Washington, DOE/EIS-0245-F, U.S. Department of Energy, Richland Operations Office, Rich 1 and, Washington.

DOE, 1996b, Fina7 Environmental Impact Statement for the Tank Waste Remediation System, DOE/EIS-0189F, U.S. Department of Energy, Richland Operations office, Washington.

DOE, 1996c, Spent Nuclear Fuels/Final Environmental Impact Statement, DOE/EIS-0245F, U.S. Department of Energy, Richland Operations Office, Richland, Washington.

National Environmental Policy Act of 1969, 42 USC 43.21 et seq.

Resource Conservation and Recovery Act of 1976, 42 USC 6901 et seq.

State Environmental Policy Act of 1971, RCW 43.21C, Revised Code of Washington, et seq.

WAC 173-303, 1996, "Dangerous Waste Regulations," Washington Administrative Code, as amended.

WAC 197-11, 1986, "Washington State Environmental Policy Act Rules, Department of Ecology," Washington Administrative Code, as amended. 


$$
\text { HNF-SO-ENV-EE-003 ReV. } 0
$$

Wagoner, J. D., 1996, Federal Facility Agreement and Consent Order, Change Control Form, M-90-96-01, (internal letter 96-EAP-116 to Chuck Clarke (EPA) and Mary Riveland (Ecology), December 16), Richland, Washington.

WHC-CM-2-14, Hazardous Material Packaging and Shipping, Westinghouse Hanford Company, Richland, Washington. 
HNF-SD-ENV-EE-003 ReV. 0

\author{
APPENDIX A \\ LOW-LEVEL WASTE INTERIM STORAGE \\ PERMITTING PLAN COST AND SCHEDULE
}


HNF-SD-ENV-EE-003 Rev. 0

This page intentionally left blank. 


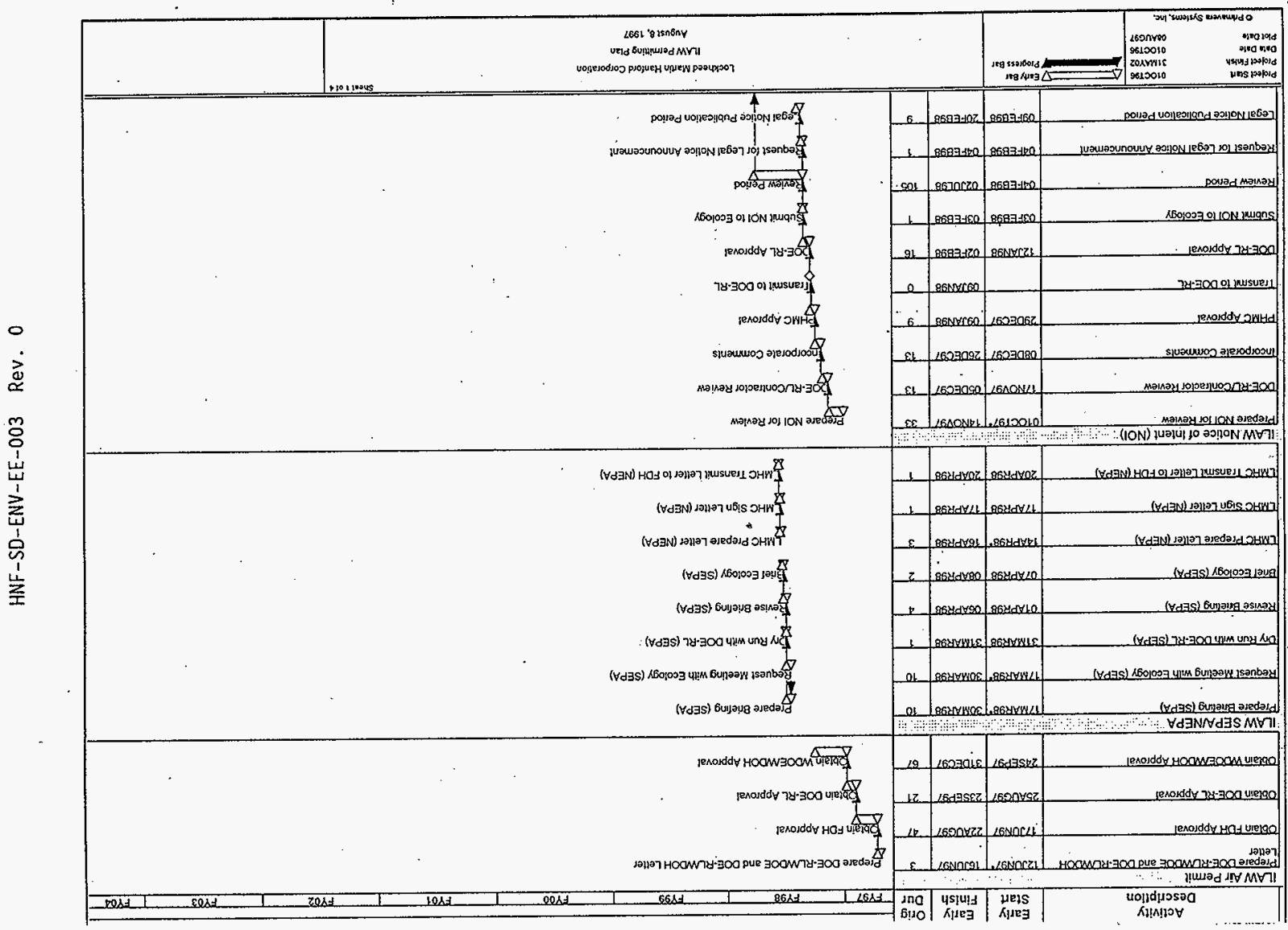




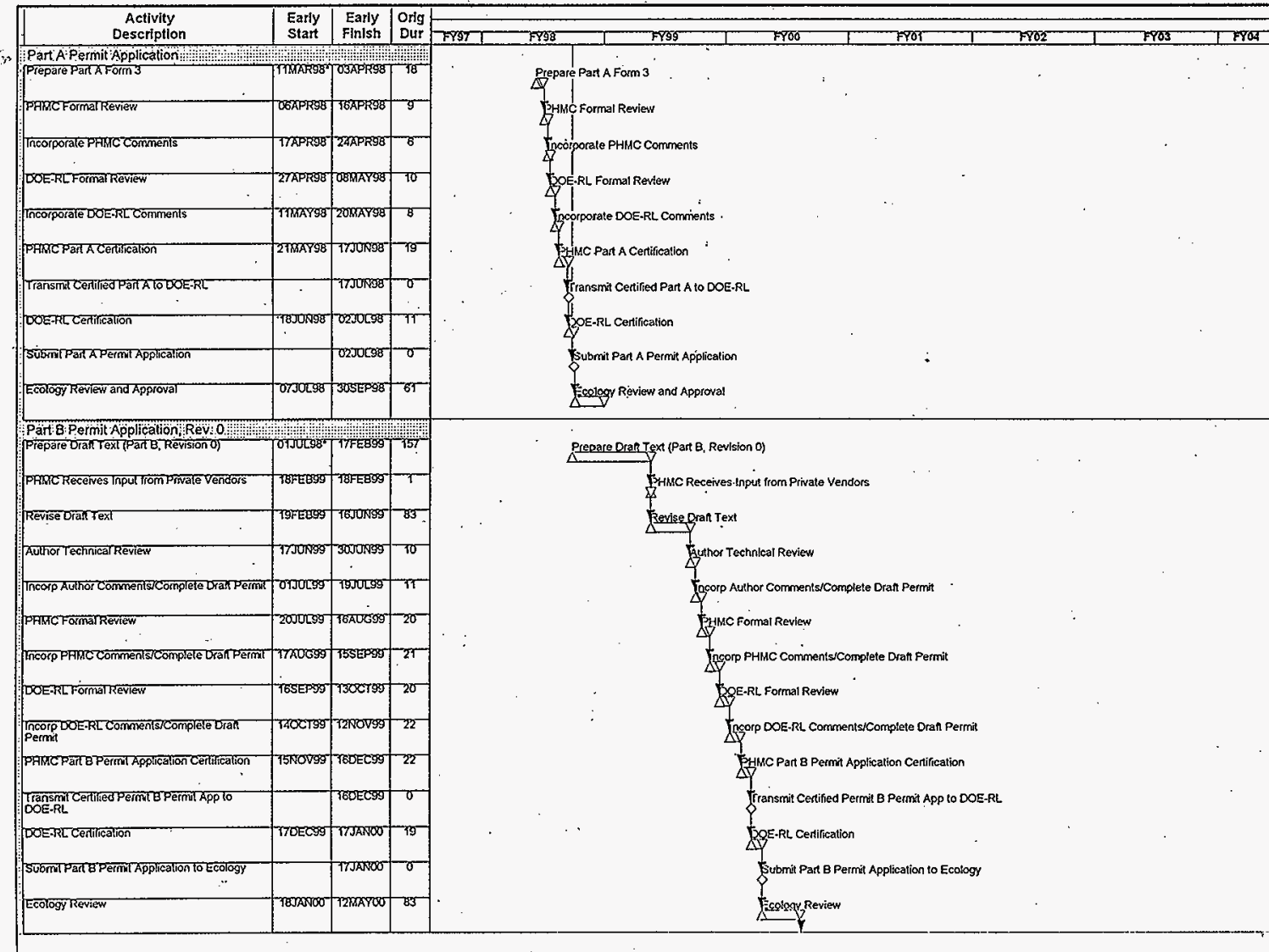


HNF-SD-ENV-EE-003 ReV. 0

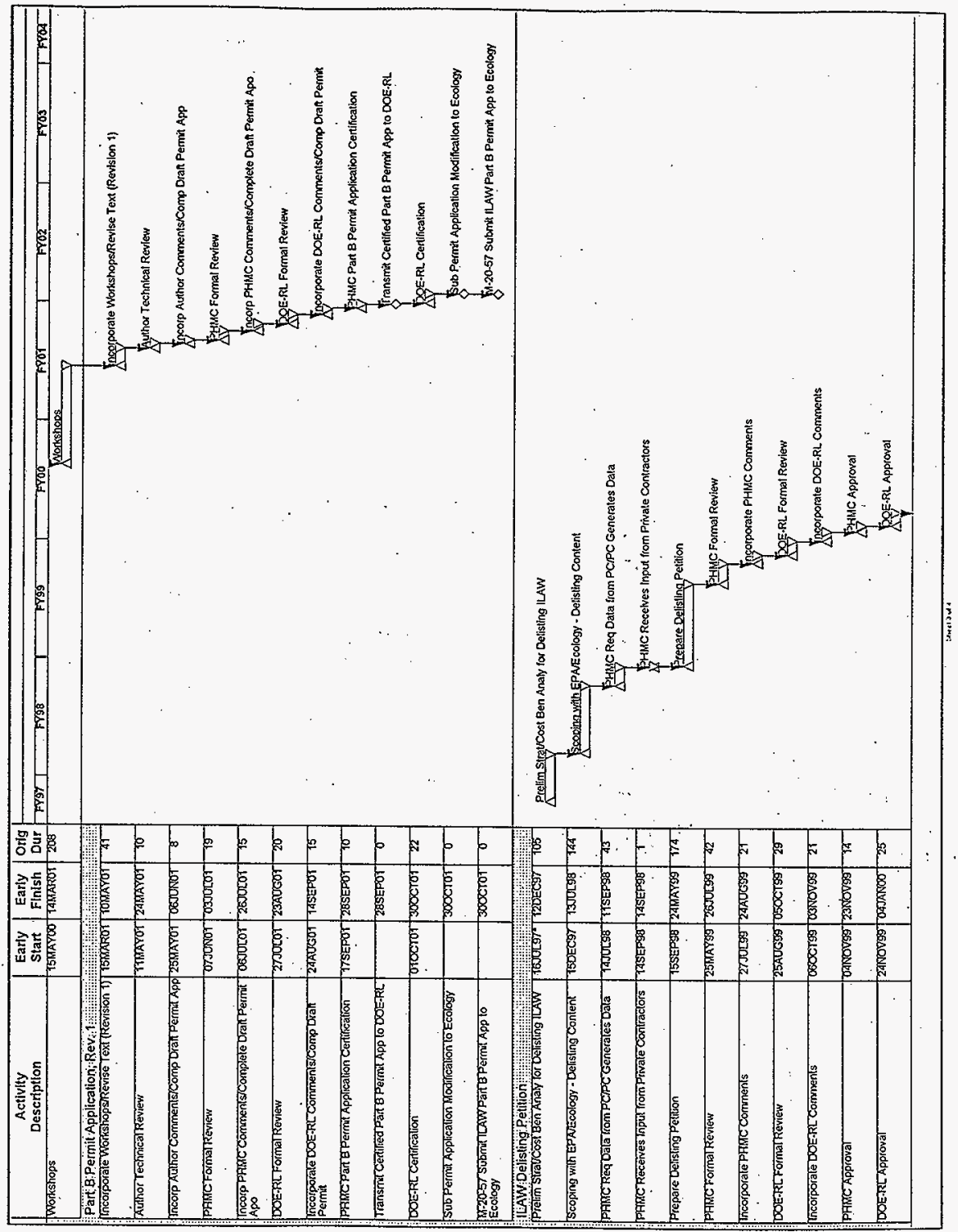




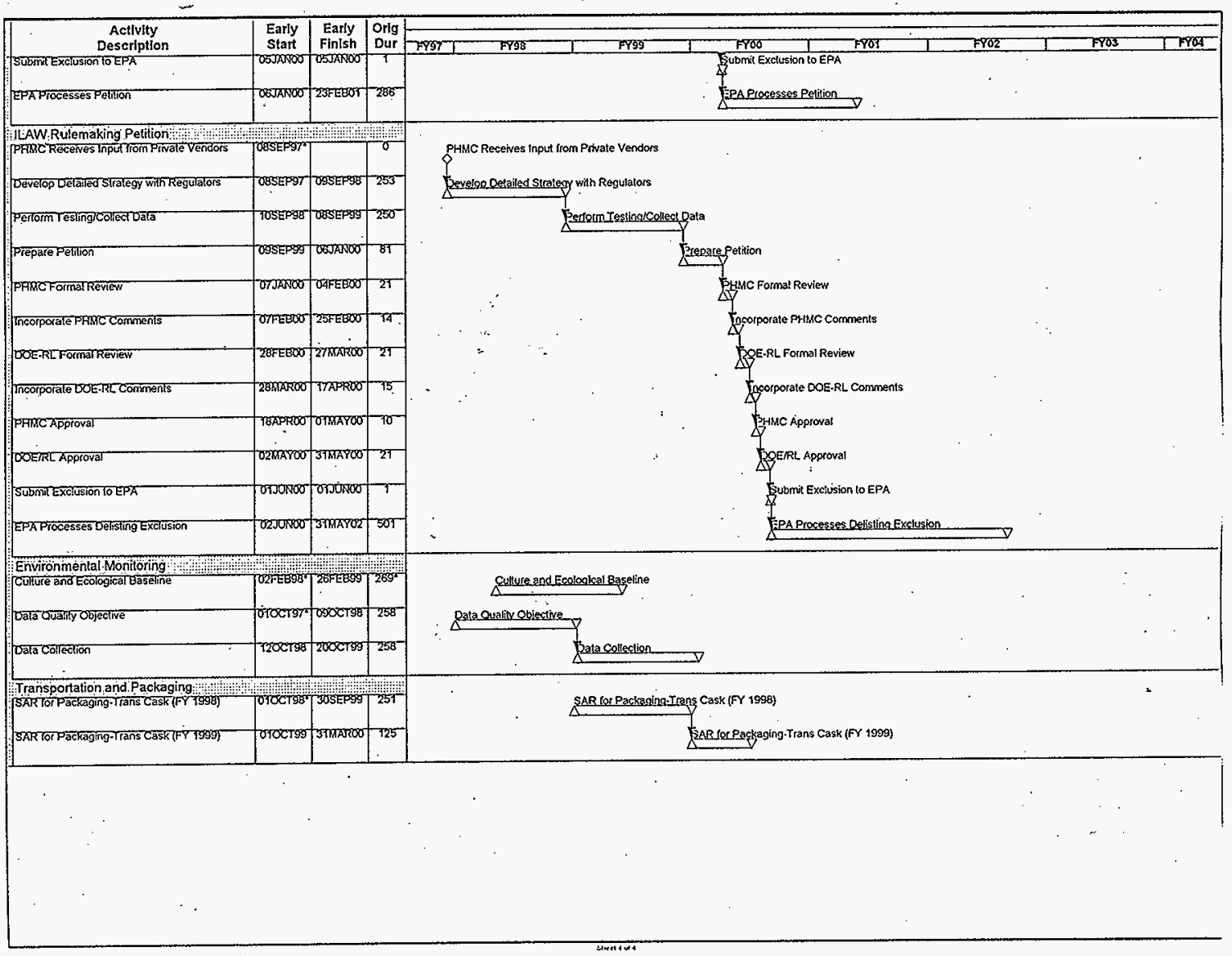




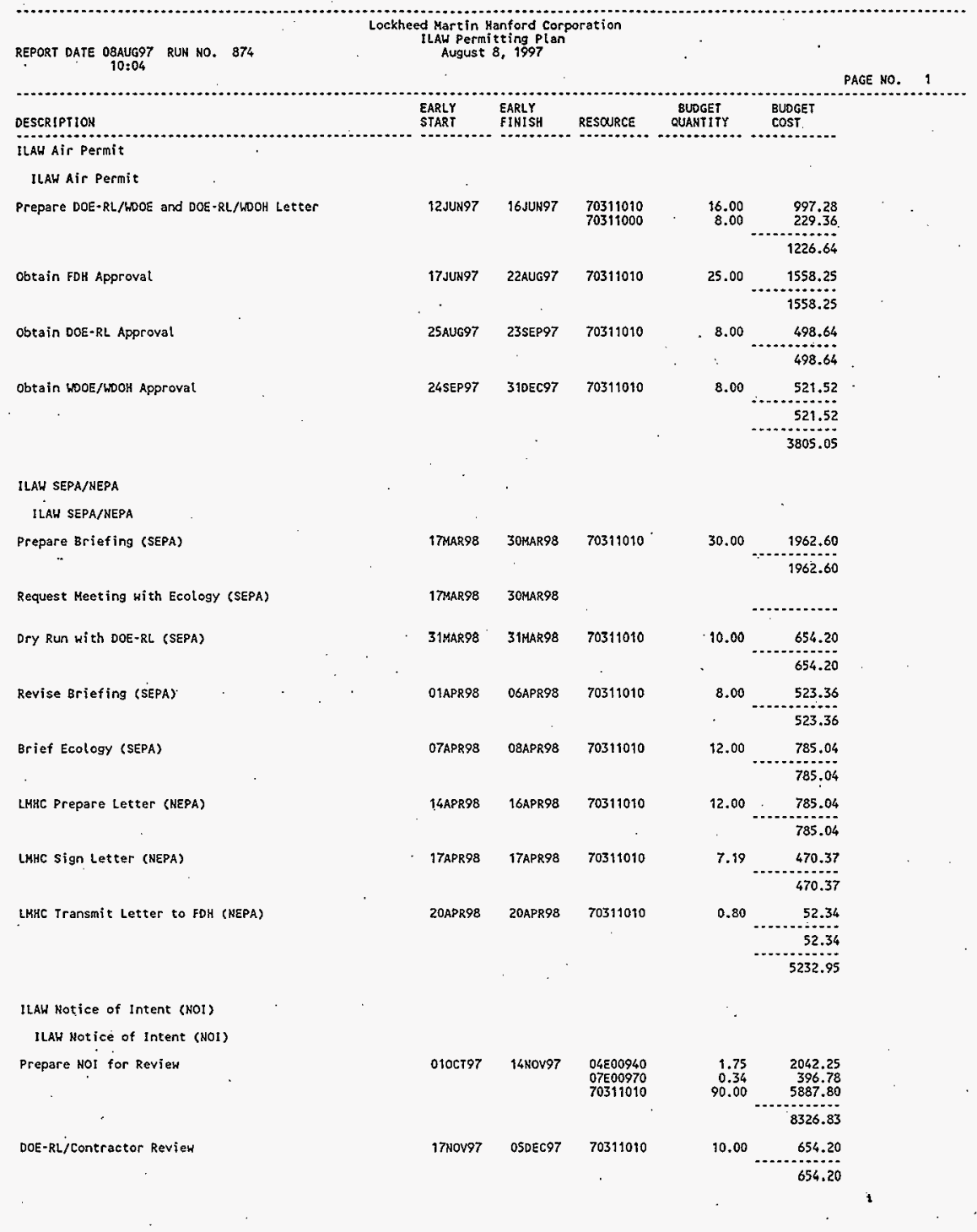




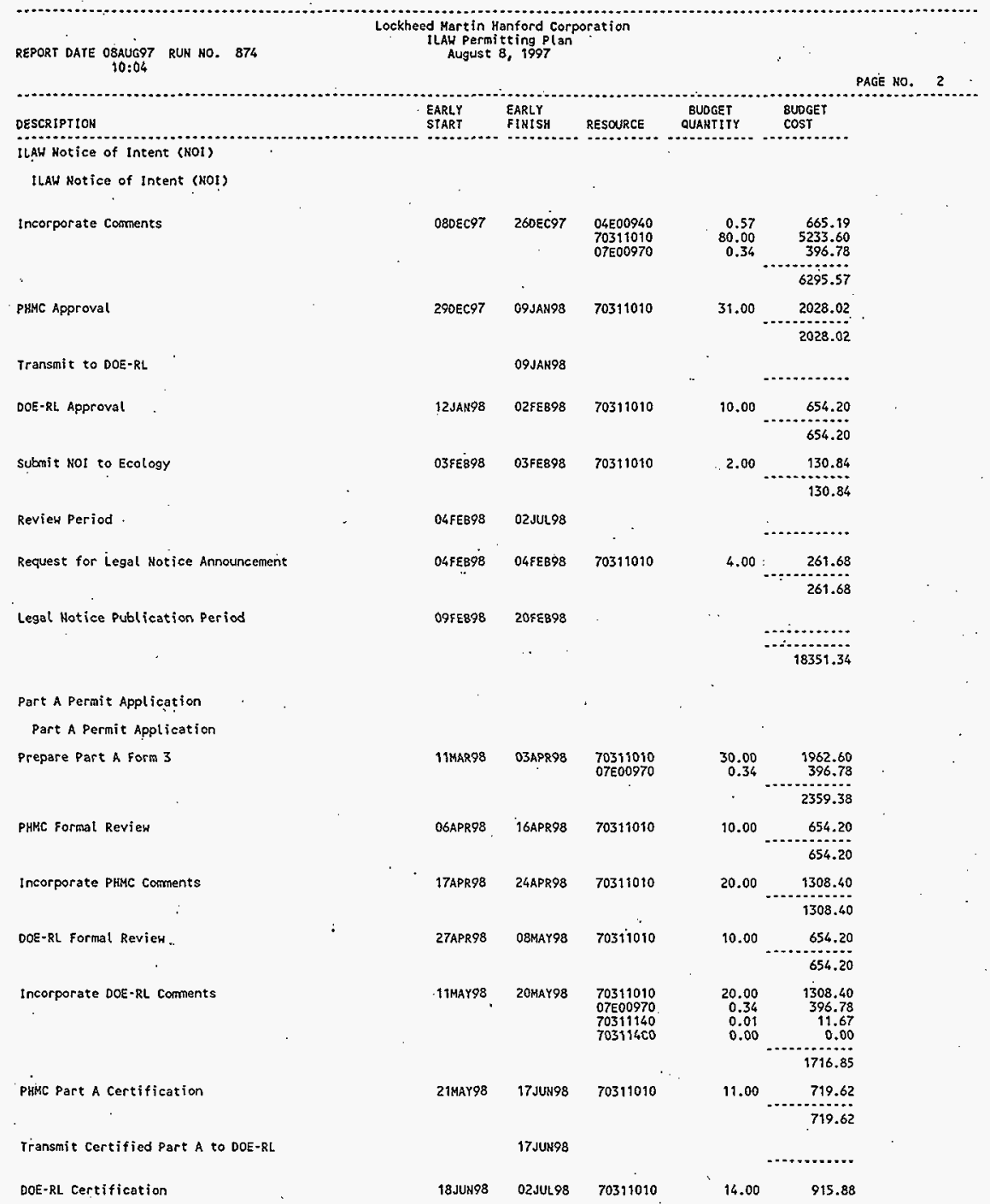




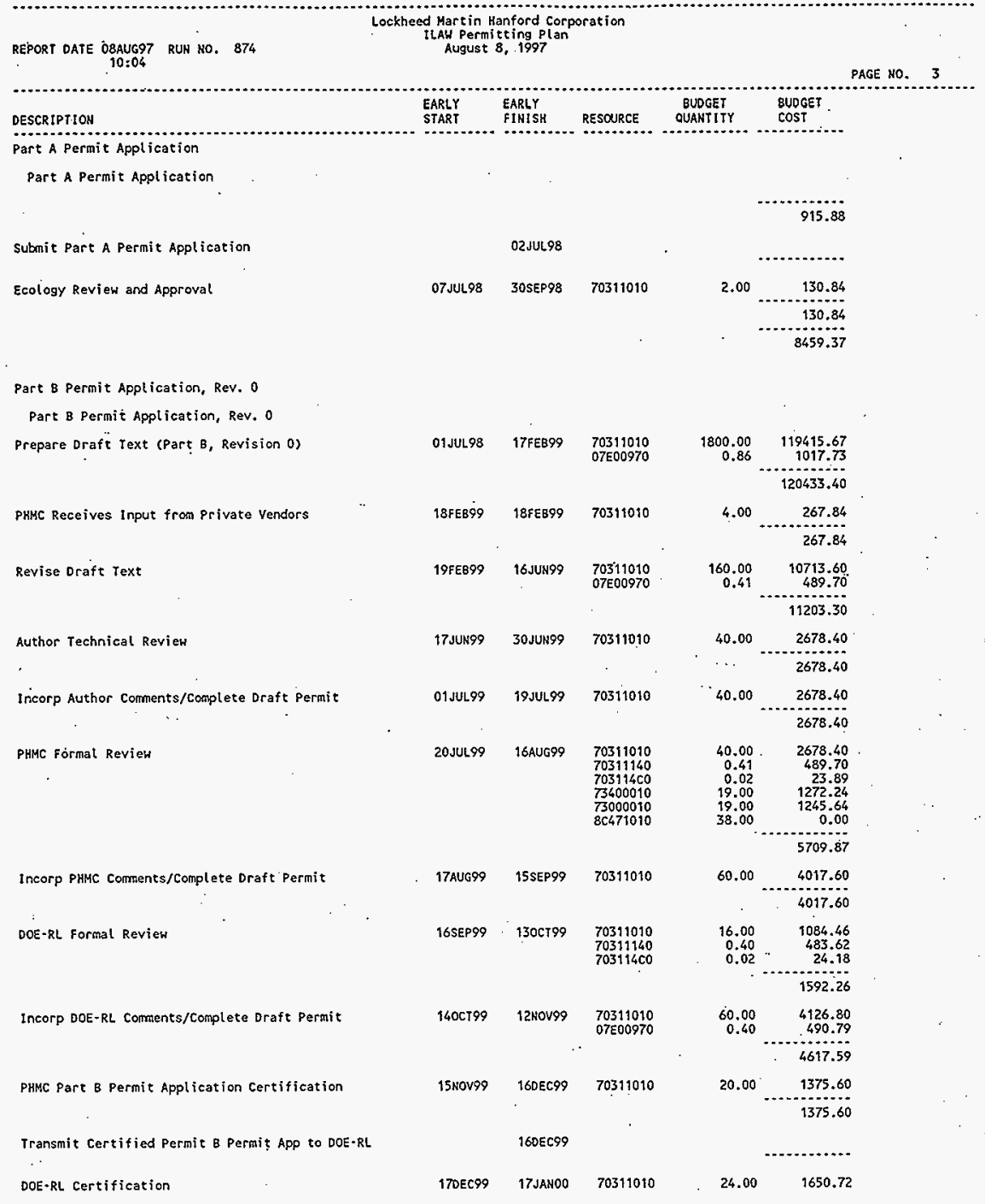




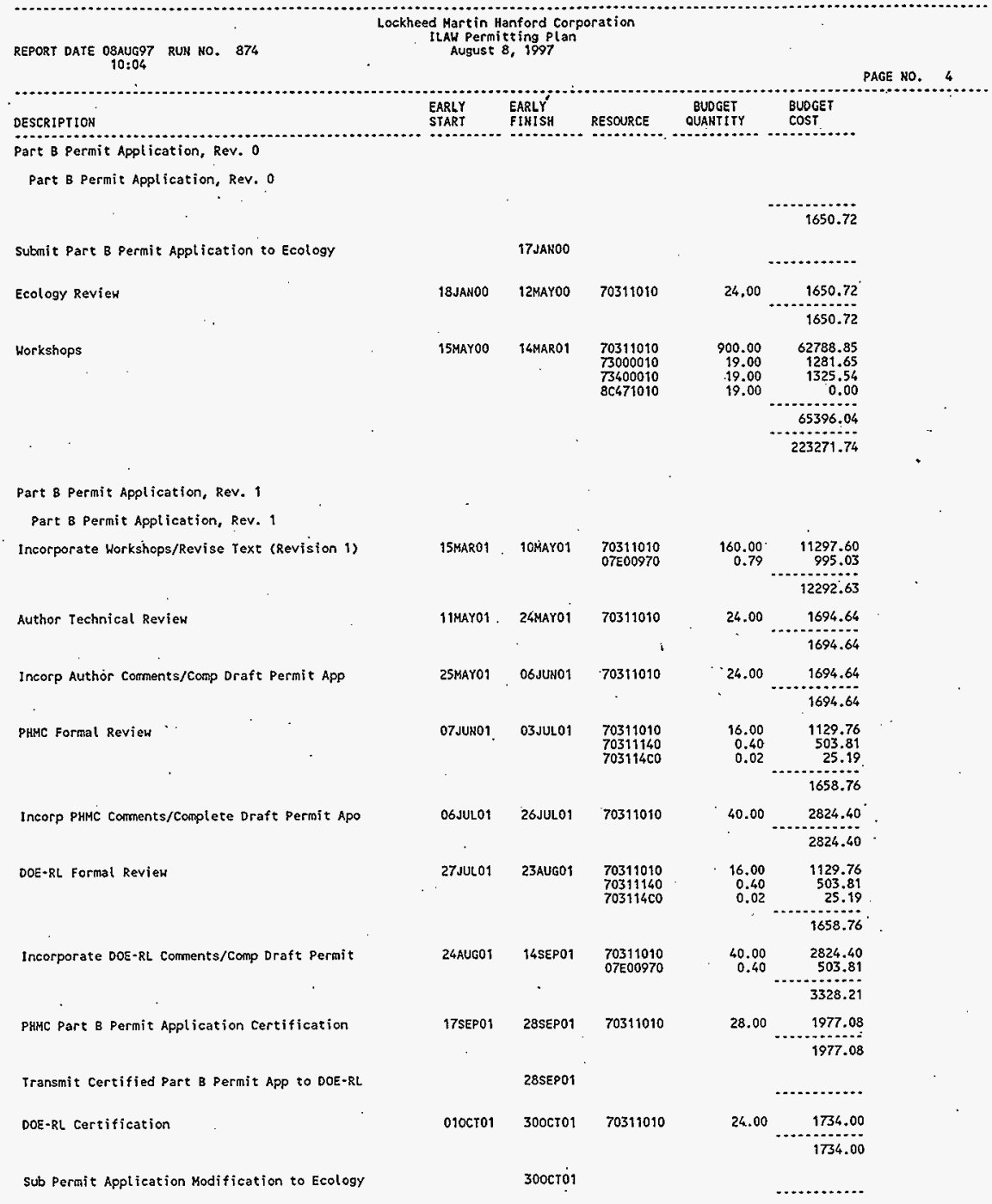




\section{HNF-SD-ENV-EE-003 Rev. 0}

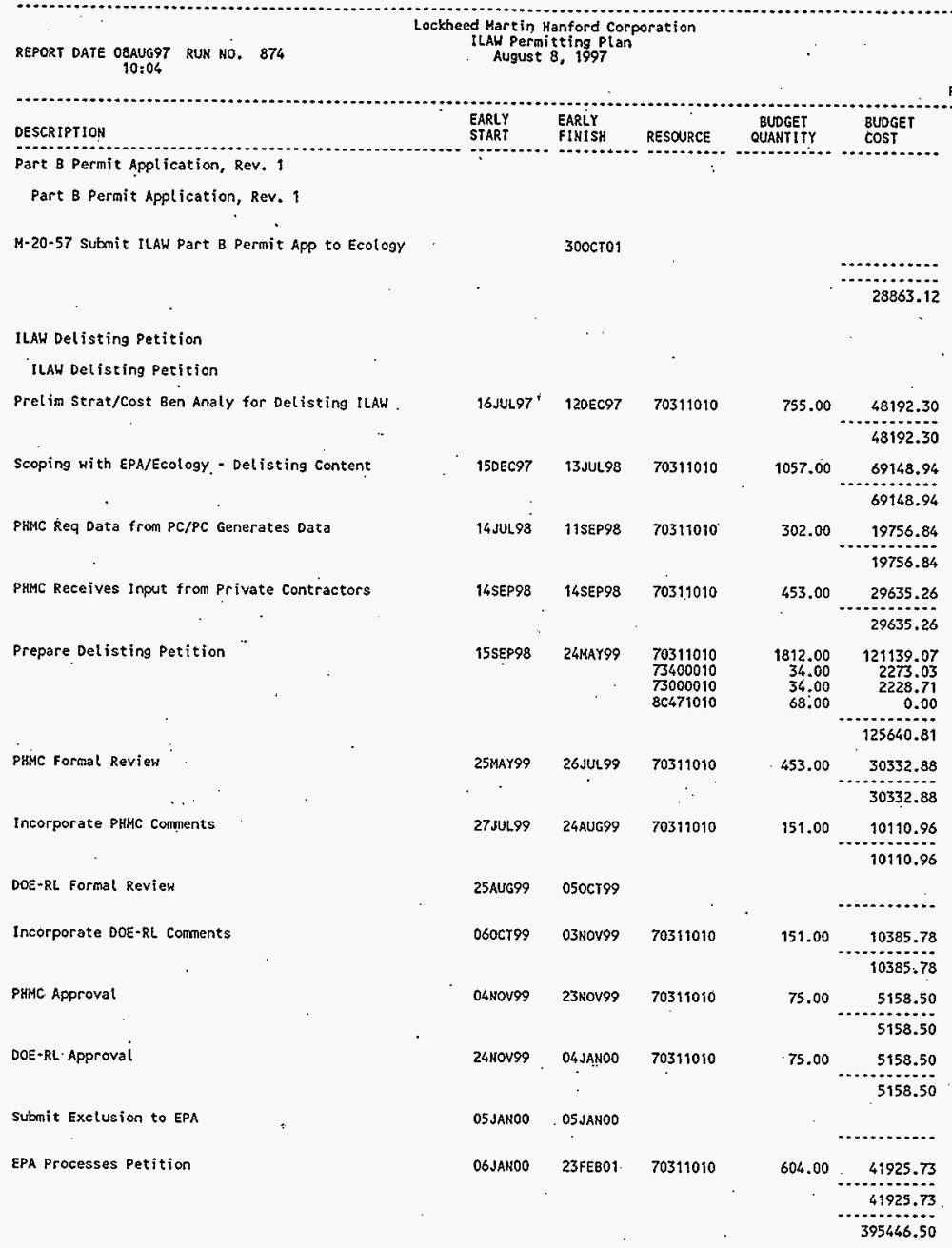




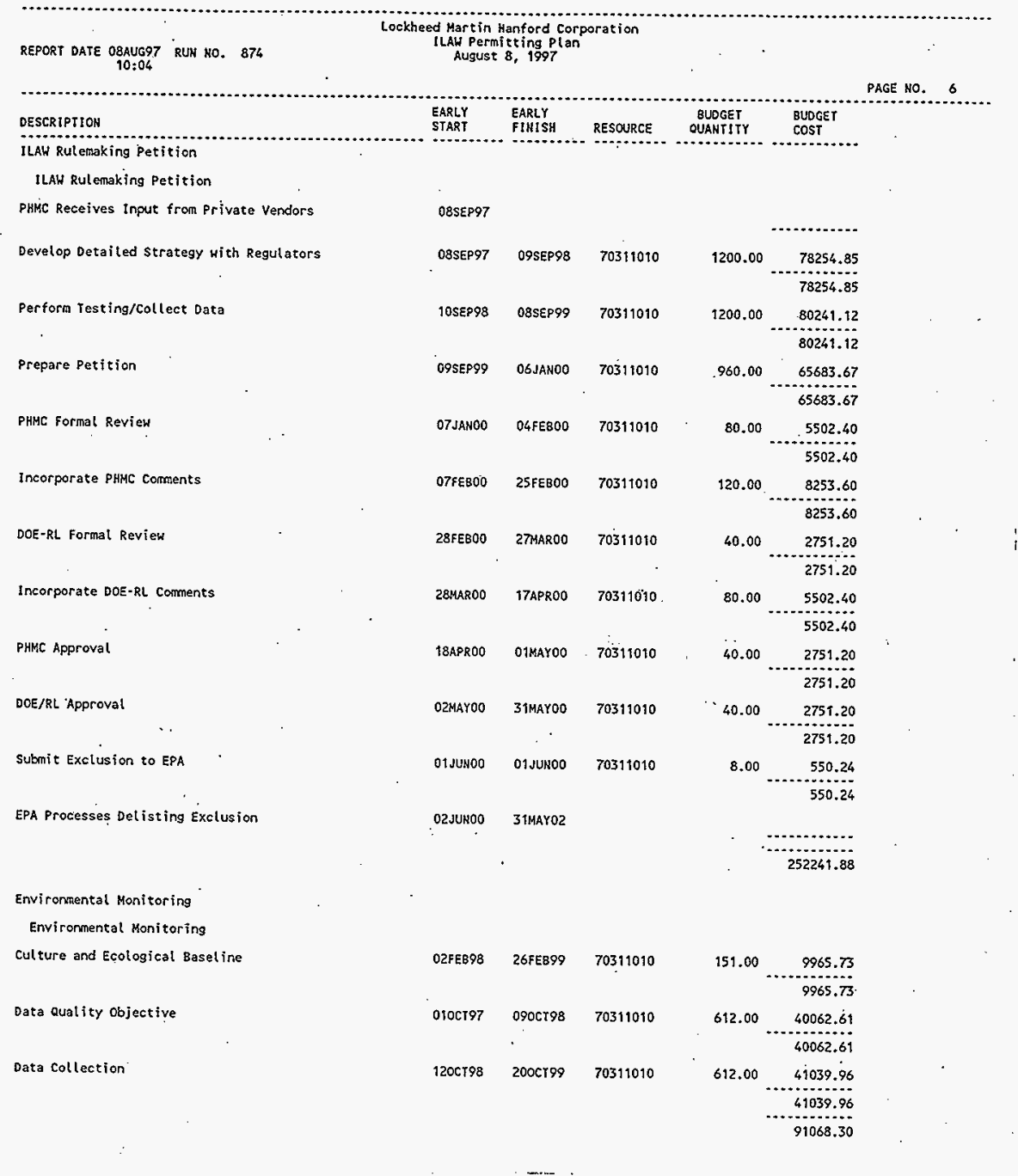


HNF-SD-ENV-EE-003 Rev. 0

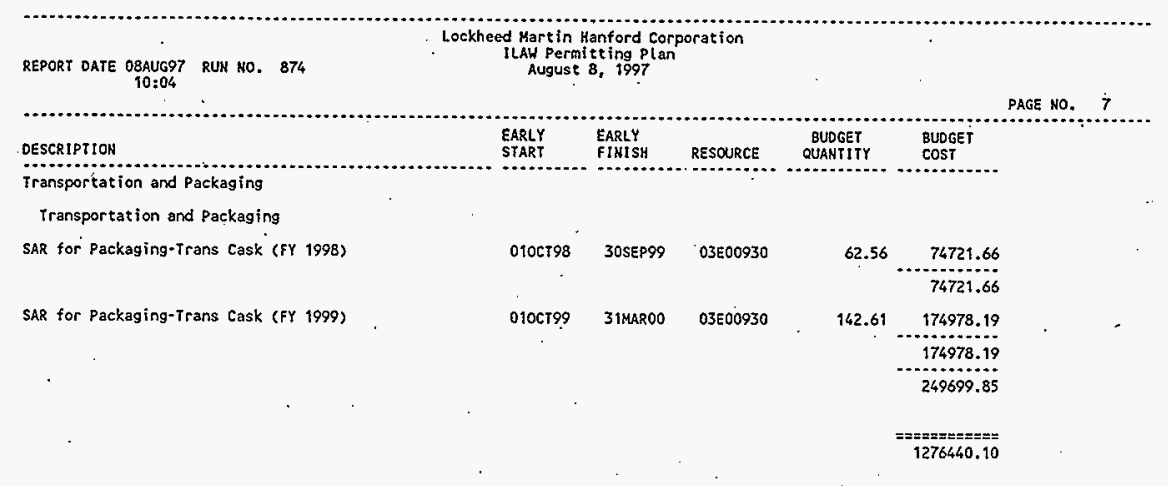


HNF-SD-ENV-EE-003 Rev. 0

This page intentionally left blank. 


$$
\text { HNF-SD-ENV-EE-003 Rev. } 0
$$

\author{
APPENDIX B \\ SCOPE OF WORK FOR \\ IMMOBILIZED LOW-ACTIVITY WASTE INTERIM STORAGE PROJECT
}

B-1 
HNF-SD-ENV-EE-003 Rev. 0

This page intentionally left blank. 
HNF-SD-ENV-EE-003 ReV. 0

\section{SCOPE OF WORK FOR IMMOBILIZED LOW-ACTIVITY WASTE INTERIM STORAGE PROJECT}

\section{Explanation of Environmental Requirements Checklists and Narrative:}

The following table identifies environmental permits, approvals, and/or requirements applicable to the project. Any "Yes" or "To be determined" answer in the applicability column will be further described in the narrative that follows the table. Some "No" answers may require special explanation and will have narratives associated with them. If this is the case, the words "See Narrative" will be stated in the applicability column. 2A contact is identified at the end of each evaluation to answer questions and/or provide additional information regarding the specific regulation in question.

\section{Description of Project Being Evaluated:}

The Immobilized Low-Activity Waste Interim Storage Facility Project, project $W-465$, includes the design and construction of a facility to provide storage space for immobilized low-activity waste (ILAW) packages, shipping and receiving of ILAW packages in transport containers on a transport vehicle, loading and unloading of ILAW packages from the transport container, package handling for placement and retrieval of ILAW within the storage area, and monitoring of the stored ILAW packages.

The overall ILAW Storage function will be responsible for transporting containers of ILAW packages from the low-level waste immobilization facility (from the Private Contractors), placing the waste packages in their designated storage locations, monitoring the packages for storage containment integrity, and if necessary eventually retrieving the packages from storage to prepare them for onsite disposal.

Project W-465 will design and furnish shipping containers for the transport of ILAW to the ILAW interim storage facility, design upgrades to the existing grout vaults necessary to accommodate a potential 50 year storage period of ILAW. The shipping containers filled with ILAW will be unloaded at the interim storage facility. The loaded shipping containers will be collected and transported to the disposal area or the interim storage area as required. 


\section{ABBREVIATIONS and ACRONYMS}

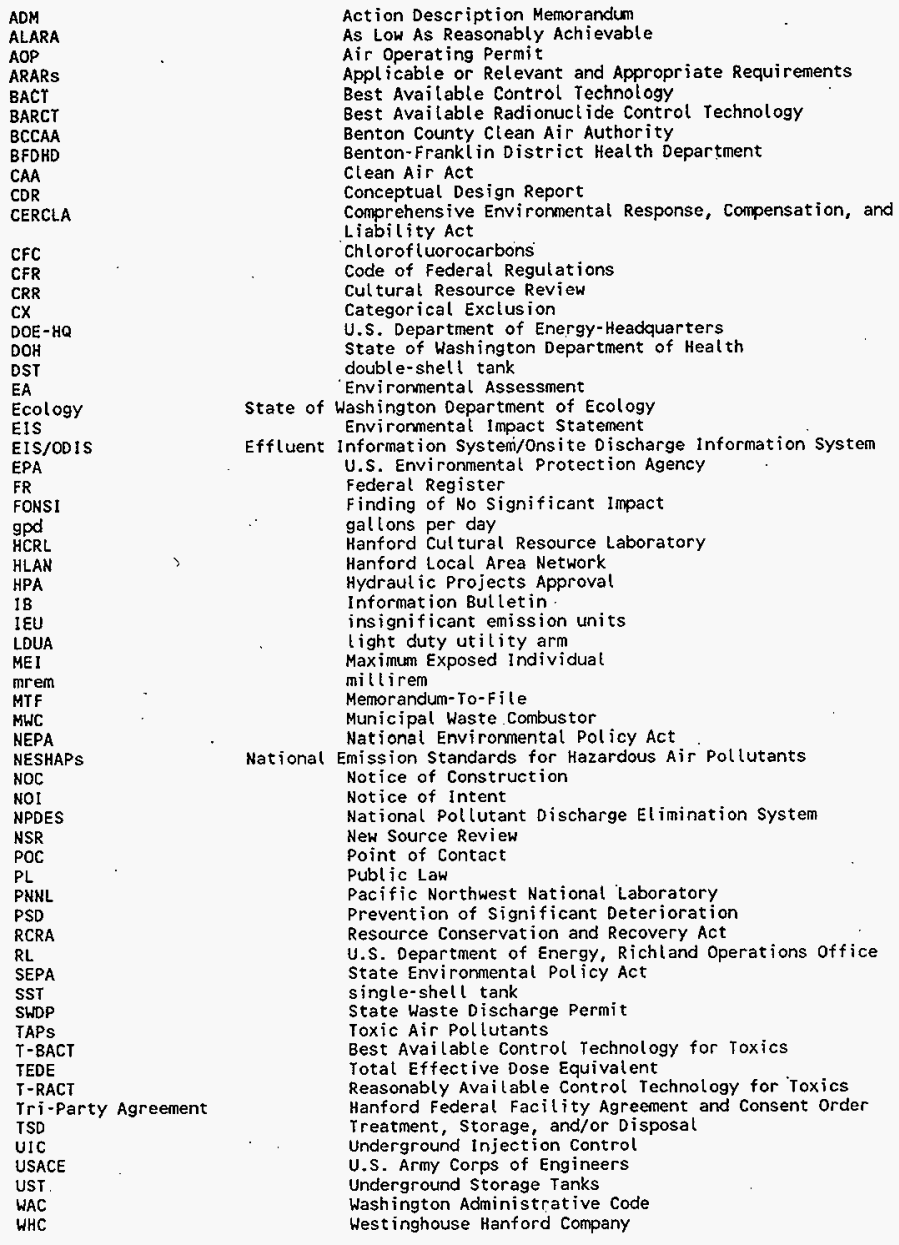

Note: This applies to the complete POC checklist and may not apply in full to individual checklists. 
HNF-SD-ENV-EE-003 ReV. 0

SUMMARY CHECKLIST OF POTENTIAL PERMITS/APPROVALS/REQUIREMENTS

\begin{tabular}{|c|c|c|c|c|c|}
\hline $\begin{array}{l}\text { ENVIRONMENT - } \\
\text { MEDIA }\end{array}$ & $\begin{array}{l}\text { PERMIT, APPROVAL, } \\
\text { - Or REQUIREMENT }\end{array}$ & REGULATION(S) & $\begin{array}{l}\text { REGULATORY } \\
\text { AGENCY }\end{array}$ & RESTRICTION & (Y or or $N)$ \\
\hline NEPA & $\begin{array}{l}\text { NEPA } \\
\text { Documentation }\end{array}$ & 10 CFR 1021 & DOE & $\begin{array}{l}\text { Title II Design } \\
\text { (Projects); } \\
\text { Procurement }\end{array}$ & \\
\hline SEPA & SEPA & WAC 197-11 & $\begin{array}{l}\text { State } \\
\text { Agency }\end{array}$ & License; Permit & \\
\hline CERCLA & ARARs & 40 CFR 300 to 400 & EPA & Construction & $\mathrm{N}$ \\
\hline \multirow[t]{4}{*}{$\begin{array}{l}\text { Nonrad. Air } \\
\text { Emissions }\end{array}$} & $\begin{array}{l}\text { New Source } \\
\text { Review/NOC; Source } \\
\text { Registration } \Downarrow \Downarrow\end{array}$ & $\begin{array}{l}\text { WAC } 173-400-040 \\
\text { WAC } 173-400-110\end{array}$ & Ecology; & Construction & \\
\hline & PSD & WAC $173-400-141$ & Ecology; & Construction & narrative) \\
\hline & TAPS & $\begin{array}{c}\text { WAC } 173-460-030 \\
-040\end{array}$ & Ecology & Construction & $\begin{array}{l}\mathrm{N} \\
\text { narratives) }\end{array}$ \\
\hline & $\begin{array}{l}\text { Dangerous and/or } \\
\text { Hazardous waste } \\
\text { air emissions }\end{array}$ & $\begin{array}{l}\text { WAC } 173-303 \\
-120(4)(\mathrm{e}),-400(3) \text {, } \\
-690 \text {, and }-691 \text {, } \\
40 \text { CFR } 264 / 265 \\
\text { Subpart CC }\end{array}$ & $\begin{array}{l}\text { Ecology } \\
\text { and } \\
\text { EPA }\end{array}$ & Operations & 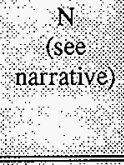 \\
\hline \multirow[t]{2}{*}{$\begin{array}{l}\text { Radioactive } \\
\text { Air } \\
\text { Emissions }\end{array}$} & NESHAPS & 40 CFR 61 , Subpart H & EPA & Construction & $\begin{array}{c}\mathrm{N} \\
(\mathrm{see} \\
\text { narrative) }\end{array}$ \\
\hline & $\begin{array}{l}\text { Radiation Protection - } \\
\text { Air Emissions }\end{array}$ & WAC 246-247-060 & $\mathrm{DOH}$ & $\begin{array}{l}\text { Construction; } \\
\text { Operation }\end{array}$ & $\begin{array}{c}\mathrm{N} \\
\text { (see } \\
\text { narrative) }\end{array}$ \\
\hline $\begin{array}{l}\text { All Air } \\
\text { Emissions }\end{array}$ & Air Operating Permit & WAC . 173-401 & $\begin{array}{l}\text { Ecology; } \\
\text { DOH; EPA }\end{array}$ & Operation & Narrative \\
\hline Asbestos & NOI & $\begin{array}{l}\text { BCCAA Reg. 1, } \\
\text { Article } 8 ; 40 \text { CFR } 61 \text {, } \\
\text { Subpart M }\end{array}$ & BCCAA & $\begin{array}{l}\text { Before Working } \\
\text { with Asbestos }\end{array}$ & $\mathrm{N}$ \\
\hline
\end{tabular}


HNF-SD-ENV-EE-003 ReV. 0

\begin{tabular}{|c|c|c|c|c|c|}
\hline $\begin{array}{l}\text { ENVIRONMENT- } \\
\text { MEOIA }\end{array}$ & $\begin{array}{l}\text { PERMIT, APPROVAL, } \\
\text { or REQUTREMENT }\end{array}$ & REGULATION(S) & $\begin{array}{l}\text { REGULATORY } \\
\text { AGENCY }\end{array}$ & RESTRICTION & $\left(Y^{A P P}\right.$ or $\left.N\right)$ \\
\hline $\begin{array}{l}\text { Outdoor or } \\
\text { Unconfined } \\
\text { Burning }\end{array}$ & Burn Permit & $\begin{array}{l}\text { WAC 173-425; } \\
\text { BCCAA Reg. } 1 \text {, } \\
\text { Article } 5\end{array}$ & $\begin{array}{l}\text { Hanford } \\
\text { Fire } \\
\text { Department } \\
\text { BCCAA }\end{array}$ & Open Burning & $\mathrm{N}$ \\
\hline $\begin{array}{l}\text { Ozone } \\
\text { Depleting } \\
\text { Substances/ } \\
\text { CFCs }\end{array}$ & $\begin{array}{l}\text { Release Prevention; } \\
\text { Recovery/Recycle; } \\
\text { Certification Labeling }\end{array}$ & 40 CFR 82 & Ecology & $\begin{array}{l}\text { Reporting; } \\
\text { Training; } \\
\text { Operation }\end{array}$ & $\mathrm{N}$ \\
\hline \multirow{3}{*}{$\begin{array}{l}\text { Soil Column } \\
\text { Waste Water } \\
\text { Disposal }\end{array}$} & SWDP & WAC $173-216$ & Ecology & Operation & $\mathrm{N}$ \\
\hline & $\begin{array}{l}\text { Approval of Engr. } \\
\text { Report, Plans \& } \\
\text { Specs., and O\&M } \\
\text { Manual }\end{array}$ & WAC $173-240$ & Ecology & Construction & $\mathrm{N}$ \\
\hline & $\begin{array}{l}\text { UIC Permit/ } \\
\text { Registration }\end{array}$ & WAC $173-218$ & Ecology & Operation & $\mathrm{N}$ \\
\hline \multirow[t]{5}{*}{$\begin{array}{l}\text { Domestic } \\
\text { Waste Water } \\
\text { Disposal }\end{array}$} & $\begin{array}{l}\text { Septic Systems } \\
<14,500 \text { gpd } \\
\text { Capacity Design } \\
\text { Approval }\end{array}$ & WAC $246-272$ & DOH & Construction & $\mathrm{N}$ \\
\hline & $\begin{array}{l}\text { Septic Systems } \\
>14,500 \text { gpd } \\
\text { Capacity Design } \\
\text { Approval }\end{array}$ & $\begin{array}{l}\text { WAC } 173-216 \\
\text { WAC } 173-240\end{array}$ & Ecology & Construction & $\mathrm{N}$ \\
\hline & Pretreatment Permit & $\begin{array}{l}40 \text { CFR } 403 ; \\
\text { City Ordinance }\end{array}$ & $\begin{array}{l}\text { City of } \\
\text { Richland }\end{array}$ & $\begin{array}{l}\text { Discharge to City } \\
\text { Sewage Facility }\end{array}$ & $\mathrm{N}$ \\
\hline & Operator Certification & WAC $173-230$ & Ecology & Operation & $\mathbf{N}$ \\
\hline & Discharge Standards & WAC $173-221$ & Ecology & Discharge & $N$ \\
\hline \multirow{3}{*}{$\begin{array}{l}\text { Surface } \\
\text { Waste Water } \\
\text { Disposal }\end{array}$} & NPDES Permit & 40 CFR 122 & EPA & Operation & $\mathrm{N}$ \\
\hline & $\begin{array}{l}\text { Storm Water } \\
\text { Discharge Under } \\
\text { General Permit }\end{array}$ & 57 FR No. 175 & EPA & $\begin{array}{l}\text { River } \\
\text { Construction }\end{array}$ & $\mathrm{N}$ \\
\hline & $\begin{array}{l}\text { U.S. Dept of Army } \\
\text { Permit }\end{array}$ & 33 CFR 325 & USACE & $\begin{array}{l}\text { River } \\
\text { Construction }\end{array}$ & $\mathrm{N}$ \\
\hline
\end{tabular}


HNF-SD-ENV-EE-003 ReV. 0

\begin{tabular}{|c|c|c|c|c|c|}
\hline $\begin{array}{l}\text { ENVIRONMENT- } \\
\text { MEDIA }\end{array}$ & $\begin{array}{l}\text { PERMIT, APPROVAL, } \\
\text { Or REQUIREMENT }\end{array}$ & REGULATION(S) & $\begin{array}{l}\text { REGULATORY } \\
\text { AGENCY }\end{array}$ & RESTRICTION & (YPP. \\
\hline & Sèction 10 Permit & $\begin{array}{l}33 \text { CFR 320; } \\
33 \text { CFR } 322\end{array}$ & USACE & $\begin{array}{l}\text { River } \\
\text { Construction }\end{array}$ & N \\
\hline & Nationwide Permits & 33 CFR 330 & USACE & $\begin{array}{l}\text { River } \\
\text { Construction }\end{array}$ & \\
\hline \multirow{7}{*}{. } & $\begin{array}{l}\text { Hydraulic Projects } \\
\text { Permit }\end{array}$ & WAC $220-110$ & $\begin{array}{l}\text { WA State } \\
\text { Dept. of } \\
\text { Fisheries }\end{array}$ & $\begin{array}{l}\text { River } \\
\text { Construction }\end{array}$ & $\mathrm{N}$ \\
\hline & $\begin{array}{l}\text { Shoreline } \\
\text { Development Permit }\end{array}$ & WAC $173-14$ to -20 & $\begin{array}{l}\text { Benton } \\
\text { County }\end{array}$ & $\begin{array}{l}\text { River/Island } \\
\text { Construction }\end{array}$ & $\mathrm{N}$ \\
\hline & Aquatic Lands Lease & WAC $332-30$ & DNR & Construction & $\mathrm{N}$ \\
\hline & $\begin{array}{l}\text { Hanford Reach Study } \\
\text { Act Notification }\end{array}$ & PL 100-605 & $\begin{array}{l}\text { U.S. Park } \\
\text { Service }\end{array}$ & $\begin{array}{l}\text { Construction } \\
\text { within } 1 / 4 \mathrm{mi} \text {. of } \\
\text { River }\end{array}$ & $\mathrm{N}$ \\
\hline & $\begin{array}{l}\text { Water Quality } \\
\text { Modification Permit }\end{array}$ & WAC $173-201$ & Ecology & $\begin{array}{l}\text { River } \\
\text { Construction }\end{array}$ & $\mathrm{N}$ \\
\hline & $\begin{array}{l}\text { Certification of } \\
\text { NPDES Permit }\end{array}$ & 40 CFR 121 & Ecology & Operation & $\mathrm{N}$ \\
\hline & Categorical Standards & 40 CFR 405 to 471 & EPA & Operation & $\mathrm{N}$ \\
\hline \multirow[t]{3}{*}{$\begin{array}{l}\text { Drinking } \\
\text { Water } \\
\text { Supply }\end{array}$} & $\begin{array}{l}\text { Approval of Engr. } \\
\text { Report, Plans \& } \\
\text { Specs. }\end{array}$ & WAC $246-290$ & $\mathrm{DOH}$ & Construction & $N$ \\
\hline & System ID. Number & WAC $246-290$ & $\mathrm{DOH}$ & Operation & $\mathrm{N}$ \\
\hline & Operator Certification & WAC $246-292$ & $\mathrm{DOH}$ & Operation & $\mathrm{N}$ \\
\hline Solid Waste & $\begin{array}{l}\text { Solid Waste Handling } \\
\text { Facility Permit }\end{array}$ & WAC $173-304$ & BFDHD & Construction & $\begin{array}{l}\mathrm{N}+ \\
(\mathrm{See} \\
\mathrm{Nanrative}\end{array}$ \\
\hline $\begin{array}{l}\text { Dangerous } \\
\text { Waste }\end{array}$ & $\begin{array}{l}\text { Dangerous Waste } \\
\text { Permit (RCRA } \\
\text { Part A and B) }\end{array}$ & $\begin{array}{l}\text { WAC } 173-303-800 \\
\text { through-860; } \\
40 \text { CFR 264; } \\
40 \text { CFR 265; } \\
40 \text { CFR 270 }\end{array}$ & Ecology & $\begin{array}{l}\text { Construction of } \\
\text { New Facilities or } \\
\text { Expansion of } \\
\text { Existing Facilities }\end{array}$ & $Y$ \\
\hline
\end{tabular}


HNF-SD-ENV-EE-003 ReV. 0

\begin{tabular}{|c|c|c|c|c|c|}
\hline \multirow[t]{2}{*}{$\begin{array}{l}\text { ENVIRONMENT- } \\
\text { MEDIA }\end{array}$} & $\begin{array}{l}\text { PERMIT, APPROVAL, } \\
\text { Or REQUIREMENT }\end{array}$ & REGULATION(S) & $\begin{array}{l}\text { REGULATORY } \\
\text { AGENCY }\end{array}$ & RESTRICTION & (Y or $N)$ \\
\hline & $\begin{array}{l}\text { Construction or } \\
\text { expansion of surface } \\
\text { impoundments, waste } \\
\text { piles, or landfill } \\
\text { units }\end{array}$ & WAC $173-303-335$ & Ecology & $\begin{array}{l}\text { Construction } \\
\text { quality assurance } \\
\text { plans, program, } \\
\text { and certification }\end{array}$ & \\
\hline UST & Tank Permit & WAC $173-360$ & Ecology & Operation & N. \\
\hline All Media & $\begin{array}{l}\text { Floodplain, Wetland } \\
\text { Assessment }\end{array}$ & 10 CFR 1022 & DOE & $\begin{array}{l}\text { Any Surface } \\
\text { Disturbance }\end{array}$ & \\
\hline & $\begin{array}{l}\text { Cultural Resource } \\
\text { Review }\end{array}$ & 36 CFR. 800 & DOE & $\begin{array}{l}\text { Any Surface } \\
\text { Disturbance; } \\
\text { Modification of } \\
\text { Bldgs. Eligible } \\
\text { for Listing on } \\
\text { Historical } \\
\text { Register. }\end{array}$ & : \\
\hline & Excavation Permit & 36 CFR 800 & DOE & Any Excavation & $\mathrm{x}$ \\
\hline & $\begin{array}{l}\text { Ecological } \\
\text { Compliance Review }\end{array}$ & $\begin{array}{l}10 \text { CFR } 1021 ; \\
50 \text { CFR } 402.6 \\
\text { DOE Order } 5484.1\end{array}$ & USFWS & $\begin{array}{l}\text { Construction; } \\
\text { Habitat } \\
\text { Modification }\end{array}$ & $\begin{array}{r}\mathrm{X} \\
\\
\end{array}$ \\
\hline & $\begin{array}{l}\text { Preoperational } \\
\text { Monitoring of } \\
\text { Facilities, Sites, and } \\
\text { Operations }\end{array}$ & DOE.Order 5400.1 & DOE & Operation & ४ \\
\hline & $\begin{array}{l}\text { Radiation Protection } \\
\text { Standards }\end{array}$ & DOE Order 5400.5 & DOE & Construction & $Y$ \\
\hline
\end{tabular}


NEPA

NEPA Documentation - Title 10, CFR 1021

A NEPA review is required for all proposed actions at the Hanford Site. Documentation of the completed NEPA review process could include an EIS, an EA or a CX. The EIS is required for proposed major federal actions that could significantly affect the quality of the human environment. In cases where the need for an EIS is uncertain, an EA is prepared. A CX is issued by RL if the proposed action clearly would have no significant impact on the quality of the human environment. However, most actions determined to be categoricaliy excludable must be documented. A NEPA Documentation Request Checklist is available on Jetform on the Hanford Local Area Network that can be completed and forwarded to WHC NEPA Services to initiate the necessary review process. NEPA Documentation must be completed before starting Title II Design.

Note: All cultural resource surveys and ecological survey/reviews must be completed before any NEPA documentation is submitted to RL. 
EVALUATION: DOE/EIS-0189 Final Environmental Impact Statement for the Tank Waste Remediation System, Section 3.4.10, "Descriptions and Comparisons of Alternatives - Phased Implementation Alternative", and Volume 2, Appendix B, Section B.3.9.1, "Descriptions of Alternatives - Phased Implementation Alternative", include a description of the Phase 1 Low Activity Waste activities that would be covered by the Environmental Impact Statement.

These sections state that the Low Activity Waste would be processed using a technology that would meet Low Activity Waste acceptance specifications, with vitrification technology being used in the EIS for the purposes of comparing environmental impacts from other alternatives. The Immobilized Low Activity Waste will be $\mathrm{placed}$ into disposal containers and transported to the existing grout vaults for interim storage until the permanent onsite disposal vaults are constructed during Phase 2 of the Privatization contract. The LAW placed in interim storage during Phase'l will be retrieved and transported to the LAW disposal vaults during Phase 2.

The TWRS EIS addresses LAW operations implemented under Phase 1, placing the immobilized LAW into containers, transporting the immobilized waste to onsite interim storage facilities, modification of the existing Grout Vaults to accommodate interim LAW storage during Phase 1 operations. The Grout Vault modifications would include those required to allow placement and interim storage of the LAW disposal containers pending future retrieval and disposal during Phase 2.

It should be noted that the following ILAW activities are not covered by the TWRS EIS for Phase 1: a.) disposal of LAW - all disposal occurs in Phase 2; b.) construction of additional ILAW interim storage capacity.

For additional information contact L. E. Borneman (373-2821) or B. G. Erlandson $(372-2678)$.

SEPA

SEPA Documentation - WAC 197-11

SEPA is the State or local equivalent of NEPA that requires evaluation of environmental impacts associated with a project before it can be approved. SEPA checklist is completed if required by Ecology (typically only if some state permit is needed). An EA under NEPA may substitute for the SEPA checklist. Ecology will determine if a State EIS is required or will issue a determination of nonsignificance. 
EVALUATION: The Washington State Department of Ecology was the lead State Agency in the preparation of DOE/EIS-0189 (Final Environmental Impact Statement for the Tank Waste Remediation System). The TWRS EIS and its Record of Decision will satisfy the SEPA requirements for LAW activities addressed in the TWRS EIS. If additional federal review of the environmental impacts from a given LAW activity would be required under NEPA (i.e., as could occur as a result of significant project change), then additional state review would be required under SEPA.

For additional information, piease contact L. E. Borneman (373-2821) or B. G. Erlandson (372-2678).

\section{CERCLA}

\section{CERCLA ARARS - 40 CFR 300 to 400}

No federai, State, or local permits are required for onsite response actions covered by CERCLA, Sections 104, 106, 120, 121, 121, or 122. This exception is allowed because onsite response actions must comply with the substantive parts of ARARs. On the Hanford Site, an activity is recognized as a CERCLA activity if the unit is identified as a CERCLA unit in the Tri-Party Agreement, or the activity is documented and performed in accordance with the CERCLA process. CERCLA remedial actions must comply with the substantive requirements of ARARs during the remedial action and upon completion of the remedial action. Additionally, removal actions, commonly called interim actions or expedited response actions, must comply with ARARs depending upon the exigencies of the circumstances and the scope of the removal action. The substantive portions of ARARs are generally required unless the removal is an emergency situation that does not allow for a planning phase to identify ARARS.

\section{EVALUATION:}

The provisions of CERCLA do not apply because the interim storage and transportation of immobilized Low Activity Waste is not a CERCLA response, removal, or remedial action. 


$$
\text { HNF-SD-ENV-EE-003 Rev. } 0
$$

\section{NONRADIOACTIVE AIR EMISSIONS}

\section{General Regulations for Air Pollution Sources - WAC 173-400-040 NSR Applicability - WAC 173-400-110}

Before a new or modified source of regulated air emissions is constructed, installed, or established, Ecology must review plans, specifications, associated information, and NOCs related to the new or modified source.

An NOC is a written application to permit construction of a new source or modification of an existing source. The application describes the proposed design, assesses potential impacts to the public and environment, and provides an assessment of BACT. An NOC for nonradioactive air emissions may be required because of requirements of two regulations: sources subject to WAC 173-400 (including 40 CFR 60 and 61) and WAC 173-460 may need an NOC prepared for preconstruction approval according to each regulation. In some Cases a single, combined NOC may be submitted for approval by the appropriate state or local agency. The descriptions under the following subtitles identify these specific regulations and NOC requirements.

PSD - WAC 173-400-141

Any increased emission of criteria pollutants from a new or modified source may trigger a significant modification as defined by 40 CFR 52.21. Potential annual amounts of expected increases must be considered. Preconstruction approval may be required by Ecology. The criteria pollutants include:

- Carbon monoxide

- Nitrogen oxides

- Sulfur dioxides

- Particulate matter and PM-10

- Ozone (volatile organic compounds)

- Lead (elemental)

- Fluorides

- Sulfuric acid mist

- Total reduced sulfur compounds (including $\mathrm{H}_{2} \mathrm{~S}$ )

- CFCs 11, 12, 113, 114, 115

- Halons 1211, 1301, 2402 .

- MWC acid gases, MWC metar, and MWC organics.

If an NOC is required, the potential annual emissions of the criteria pollutants must be reported in that NOC. (See NOC Section.) 
HNF-SD-ENV-EE-003 Rev. 0

\section{EVALUATION:}

Based on the LAW Immobilization design specifications, the Immobilized LAW will be placed in a container that will be leak-tight, as determined by ANSI N14.5. The container will be designed to remain leak tight for 50 years under ambient temperature and pressure. Therefore, the Immobilized LAW Interim Storage Facility will not be a source of regulated emissions to the atmosphere and is not required to obtain permitting under the Clean Air Act.

Because the sealed container is a significant modification from the previous storage/disposal configuration for LAW (i.e., Grout), it is recommended that the ILAW Storage project seek forma? approval from the appropriate regulatory Agency that the containers constitute a sealed container and are therefore not subject to regulation.

For additional information contact L. E. Borneman (373-2821), or B. G. Erlandson $(372-2678)$.

Controls for New Sources of TAPS - WAC $173-460-030 ;-040$

Some key questions and requirements of an anaiysis regarding WAC 173-460 applicability include:

- Will the source emit TAPs other than non-process fugitive emissions in a significant quantity?

- Does the source fall into a source category listed in WAC 173-460 or WAC 173-400?

- Is the source exempt?

- Is this a "new source" of TAPs?

- T-BACT for TAPs is required for applicable sources having increased or new TAPS emissions.

- T-RACT for TAPs is required for projects that will cause the rate of TAPs emissions to decrease or stay the same. 


\section{EVALUATION:}

Based on the LAW Immobilization design specifications, the Immobilized LAW will be $\mathrm{placed}$ in a container that will be leak-tight, as determined by ANSI N14.5. The container will be designed to remain leak tight for 50 years under ambient temperature and pressure. Therefore, the Immobilized LAW Interim Storage Facility will not be a source of regulated emissions to the atmosphere and is not required to obtain permitting under the Clean Air Act.

Because the sealed container is a significant modification from the previous storage/disposal configuration for LAW (i.e., Grout), it is recommended that the ILAW Storage project seek formal approval from the appropriate regulatory Agency that the containers constitute a sealed container and are therefore not subject to regulation.

For additional information contact L. E. Borneman (373-2821), or B. G. Erlandson (372-2678).

\section{RADIOACTIVE AIR EMISSIONS}

NESHAPs - 40 CFR 61 , Subpart $H$

Any new stationary source of radionuclide emissions is subject to a preconstruction review and approval by the EPA, Region 10. A7so, any new physical or operational activity that will provide any increase in potential emissions of radionuclides is defined as a modification that also may require approval. 


\section{EVALUATION:}

Based on the LAW Immobilization design specifications, the Immobilized LAW will be placed in a container that will be leak-tight, as determined by ANSI N14.5. The container will be designed to remain leak tight for 50 years under ambient temperature and pressure. Therefore, the Immobilized LAW Interim Storage Facility will not be a source of regulated emissions to the atmosphere and is not required to obtain permitting under the Clean Air Act.

Because the sealed container is a significant modification from the previous storage/disposal configuration for LAW (i.e., Grout), it is recommended that the ILAW Storage project seek formal approval from the appropriate regulatory Agency that the containers constitute a sealed container and are therefore not subject to regulation.

For additional information contact L. E. Borneman (373-2821), or B. G. Erlandson (372-2678).

\section{Radiation Protection - Air Emissions - WAC 246-247-060}

\section{Registration of Source - WAC 246-247-060}

The EIS/ODIS is an annual report provided to DOE in accordance with DOE Order 5400.1 . If a source is 1 isted in the EIS/ODIS, it must be registered with the $\mathrm{DOH}$. Furthermore, the $\mathrm{DOH}$ will make a case-by-case determination regarding the need to register any new or modified source of radioactive air emissions requiring an NOC. One basis for determining if a source must be listed in the EIS/ODIS, thus requiring registration, is the WHC criterion for record sampling, Tisted in WHC-CM-7-5, Section 2.5.3.3. 


\section{EVALUATION:}

Based on the LAW Immobilization design specifications, the Immobilized LAW will be $\mathrm{placed}$ in a container that will be leak-tight, as determined by ANSI N14.5. The container will be designed to remain leak tight for 50 years under ambient temperature and pressure. Therefore, the Immobilized LAW Interim Storage Facility will not be a source of regulated emissions to the atmosphere and is not required to obtain permitting under the Clean Air Act.

Since the sealed container is a significant modification from the previous storage/disposal configuration for LAW (i.e., Grout), it is recommended that the ILAW Storage project seek formal approval from the appropriate regulatory Agency that the containers constitute a sealed container and are therefore not subject to regulation.

For additional information contact L. E. Borneman $(373-2821)$, or B. G. Erlandson (372-2678).

\section{NOC - WAC 246-247-060}

Any new activity, process, or equipment that will involve potential emissions of radionuclides to the air is subject to a preconstruction review and approval by the $\mathrm{DOH}$. Also, if the activity involves a physical or operational change at an existing source of radionuclide air emissions, and the change will result in ANY increase in the rate of emissions of radionuclides to the ambient air from the existing source, a modification will occur according to the WAC 246-247, and review and approval by the DOH is required. To determine whether a change constitutes such a modification, emissions that will result after the changes are compared to a baseline that is normally the annual rate of emissions observed from the facility, structure, or operation during the previous two years of operations. Other options for definition of the baseline exist and may be negotiated with the $\mathrm{DOH}$.

The increase may be related to such factors as increased flow rate or concentration of effluent, upstream heating or mixing of source material, or increased exposure to outside air. When determining whether increased emissions would occur, additional abatement by any planned emissions control equipment may not be factored in.

An NOC application must be filed to obtain prior DOH approval of the new or modified activity. The NOC must include a description of the new construction or modification activities with details concerning any affect the planned construction activity, or the new or changed operations would have regarding containment or release of radionuclide air emissions. The NOC must also 
include estimates of actual and potential emissions and an assessment of BARCT as defined in the WAC 246-247. For activities having lesser potential for radioactive emissions, it is possible to gain DOH approval in a streamlined manner by providing a brief description of the proposed activity (written and oral), including a summary of the information mentioned above, to the DOH during a regularly scheduled monthly meeting. DOH approvals provided at the monthly meetings are documented in meeting minutes signed by representatives of $\mathrm{DOH}$ and $\mathrm{RL}$, and represent an approved $\mathrm{NOC}$.

\section{EVALUATION:}

Based on the LAW Immobilization design specifications, the Immobilized LAW will be placed in a container that will be leak-tight, as determined by ANSI N14.5. The container will be designed to remain leak tight for 50 years under ambient temperature and pressure. Therefore, the Immobilized LAW Interim Storage Facility will not be a source of regulated emissions to the atmosphere and is not required to obtain permitting under the Clean Air Act.

Since the sealed container is a significant modification from the previous storage/disposal configuration for LAW (i.e., Grout), it is recommended that the ILAW Storage project seek formal approval from the appropriate regulatory Agency that the containers constitute a sealed container and are therefore not subject to regulation.

For additional information contact L. E. Borneman (373-2821), or B. G. Erlandson (372-2678).

\section{ALL AIR EMISSIONS}

\section{Air Operating Permit - WAC 173-401}

WAC 173-401 establishes the elements of a comprehensive Washington State air operating permit program consistent with the requirements of Title $V$ of the Federal clean Air Act. A sitewide permit is required for the Hanford facilities. This permit will address both radioactive and nonradioactive airborne emissions from all emission units that are above the listed threshold but are not limited to, criteria pollutants and hazardous air pollutants (including radionuclides). In this regulation, Ecology also has established thresholds for regulated pollutants below which emissions would be considered insignificant for the purposes of the operating permit program. Ecology has proposed new sections to Chapter 173-401 to define IEUs and activities. Categorically exempt units/activities may be omitted from the permit. other IEU items/activities must be listed on the permit, but are exempt from the administrative requirements of the permit. 
The permit will establish emission limits and conditions of operation restrictions for major sources on the Hanford Site. If a new NOC is required and an emission unit becomes operational after the permit is issued by the state, a permit revision will be required within 12 months after commencing operation. This application for modification shall be prepared in accordance with WAC 173-401-725. The NOC and permit modification can be sought concurrently. Any NOC application and associated documentation should be retained for future use in the Air Emissions Inventory that will be supporting the preparation of the title $V$ Air Operating Permit application.

\section{EVALUATION:}

Based on the LAW Immobilization design specifications, the Immobilized LAW will be placed in a container that will be leak-tight, as determined by ANSI N14.5. The container will be designed to remain leak tight for 50 years under ambient temperature and pressure. Therefore, the Immobilized LAW Interim Storage Facility will not be a source of regulated emissions to the atmosphere and is not required to obtain permitting under the Clean Air Act.

Since the sealed container is a significant modification from the previous storage/disposal configuration for LAW (i.e., Grout), it is recommended that the ILAW Storage project seek formal approval from the appropriate regulatory Agency that the containers constitute a sealed container and are therefore not subject to regulation.

For additional information contact L. E. Borneman (373-2821), or B. G. Erlandson (372-2678).

\section{ASBESTOS}

\section{Asbestos - BCCAA General Regulation 1, Article 8; 40 CFR 61, Subpart M}

Proposed reconstruction, repair, or demolition involving asbestos must be reviewed by WHC Hanford Restoration and Operations group for possible preproject notification to the BCCAA.

\section{EVALUATION:}

No notifications are required under these regulations because no reconstruction, repair, or demolition involving asbestos will be performed by this project. 
OUTDOOR OR UNCONFINED BURNING

\section{Fire - WAC 173-425; BCCAA, Regulation 1, Article 5}

Any use of unconfined burning requires a permit from the local BCCAA obtained through the Hanford Fire Department. Special burn permits are required for demolition or fire training.

\section{Evaluation:}

No permit is required under these regulations because no outdoor or unconfined burning will occur during the implementation of this project.

\section{OZONE DEPLETING SUBSTANCES/CFCS}

\section{Ozone Depleting Substances/CFCs - 40 CFR 82}

Any person who produces, transforms, destroys, imports or exports a controlled (ozone depleting) substance must perform the required reporting, training, and operations specified.

\section{EVALUATION:}

This regulation is not applicabie to this project because no ozone depleting substances will be produced, transformed, destroyed, imported, or exported within the scope of this project.

\section{SOIL COLUMN WASTE WATER DISPOSAL}

SWDP - WAC 173-216

An SWDP is required before waste materials from industrial, commercial, and municipal operations are discharged into ground and surface waters of the state and into municipal sewerage systems. An SWDP is not required for discharges of pollutants into navigable waters covered by an NPDES permit program.

\section{EVALUATION:}

Project $W-465$ does not entail the discharge of waste materials from industrial, commercial, and municipal operations into ground and surface waters of the state and into municipal sewerage systems. Therefore, this regulation is not applicable to this project. 
HNF-SD-ENV-EE-003 ReV. 0

Approval of engineering reports, plans, and specifications and operating and maintenance manual - WAC 173-240

Before construction or modification of those domestic or industrial wastewater facilities requiring Ecology wastewater discharge permits, engineering reports, plans, and specifications for the project must be submitted to and approved by Ecology. Operation and maintenance manuals must be submitted before construction is completed.

\section{EVALUATION:}

Project $W-465$ does not entail construction or modification of a domestic or industrial wastewater facilities requiring Ecology wastewater discharge permits. Therefore, this regulation is not applicable to this project.

\section{UIC Permit/Registration - WAC 173-218}

Authorization by Ecology of fluids injected through welts has been restricted to wells operational before February 29, 1984. New discharges of uncontaminated storm water and groundwater return flow, unaitered except for temperature from a ground water heat pump used for heating or cooling, are the only discharges that are not prohibited. These discharges must be registered with Ecology before construction.

\section{EVALUATION:}

Project W-465 will not entail the construction or operation of Underground Injection Wells. Therefore, this regulation is not applicable to this project.

\section{DOMESTIC WASTE WATER DISPOSAL}

Septic system approvals/permits ( $<14,500$ gpd design capacity) - WAC 246-272

$\mathrm{Pl}$ ans and specifications for construction of a new sanitary sewer system or modification of an existing system shall be submitted and approved by the DOH before construction or entering into a contract for construction. Once the installation is complete, a Professional Engineer registered in Washington State must certify that the installation has been installed according to plans and specifications approved by the DOH. In addition, an operation and maintenance manual must be submitted to the DOH.

Note: The $\mathrm{DOH}$ has taken the following position regarding modification or expansion of a drain field located in the area of a known subsurface chemical hazard that could potentially cause the plume to harm 
groundwater: No modification or expansion will be allowed, consistent with regulations established for larger on-site sewage systems, preliminary report requirements (WAC $246-272-080$ ).

\section{EVALUATION:}

Project W-465 will not include the construction of a new septic system or modification of an existing septic system with a design capacity less than $14.500 \mathrm{gpd}$. Therefore, this regulation is not applicable to this project.

Project $W-465$ will use the existing drain fields that service the existing Grout Vaults. Documentation for these septic systems should be reviewed to assure environmental compliance.

Septic System approvais/permits (>14,500 gpd design capacity) - WAC 173-216; WAC $173-240$

Septic systems with design capacities greater than 14,500 gpd are governed by State Waste Discharge Permits (WAC 173-216) and the engineering report, plan, and specification approval process described in WAC 173-240.

\section{EVALUATION:}

Project W-465 will not include the construction of a new septic system or modification of an existing septic system with a design capacity greater than 14,500 gpd. Therefore, this regulation is not applicable to this project.

Project $W-465$ will use the existing drain fields that service the existing Grout Vaults. Documentation for these septic systems should be reviewed to assure environmental compliance.

\section{Pretreatment Permit - 40 CFR 403}

New wastewater discharges to the City's sewage treatment plant may be required to submit permit applications to the city of Richland before discharging sewage, industrial waste, or other waste. Whether a permit application is needed depends on whether the activity is considered a Significant Industrial Discharge by the City or fits a national pretreatment category.

\section{EVALUATION:}

Project W-465 will not include the discharge of wastewater to the City of Richland's sewage treatment plant. Therefore, this regulation and permit are not applicable to this project. 
HNF-SD-ENV-EE-003 Rev. 0

Operator Certification - WAC 173-230

Every operator in responsibie charge of a domestic wastewater treatment plant is required to be certified at a level equal to or higher than the classification rating of the treatment plant being operated. Septic systems are excluded from requiring certified operators.

\section{EVALUATION:}

Project W-465 does not include modification of a domestic wastewater treatment plant. Therefore, this regulation is not applicable to this project.

\section{Discharge Standards and Effluent Limitations for Domestic Waste Water} Facilities - WAC 173-221

Effluent from domestic wastewater treatment facilities, except subsurface septic tank systems with capacities iess than 14,500 gallons per day, must meet the discharge standards established in this regulation.

\section{EVALUATION:}

Project $W-465$ is not a domestic wastewater treatment facility, therefore this regulation is not applicable to this project.

\section{SURFACE WASTE WATER DISPOSAL}

NPDES Permit - 40 CFR 122

Any discharge of pollutants to waters of the United States is required to have an NPOES permit before operation. The regulatory agency responsible for issuance of this permit is the EPA.

\section{EVALUATION:}

This project will not discharge liquid effluents to waters of the United States, therefore this regulation and permit are not applicable.

\section{Storm Hater Discharge under EPA NPDES General Permit -}

57 Federal Register 175, September 9, 1992

The Hanford Site is covered under two storm water permits. Permit WA-R-00-000F covers storm water runoff for the Hanford Site as a whole. Permit WA-R-10-00OF covers storm water runoff from construction projects. If there 
HNF-SD-ENV-EE-003 ReV. 0

is a potential for storm water to reach the river from construction activities; an NOI for authorization under the EPA general permit and a SWPPP must be in place at least two days before discharge from new construction sites (those begun after October 1, 1992):

\section{EVALUATION:}

Project $W-465$ will be subject to the provisions of Permit $A-R-10-000 F$ for control of storm water runoff from construction projects. Storm water runoff from Project $W-465$ does not have a potential to reach the Columbia River, therefore an NOI for authorization under the EPA general permit and a SWPPP are not required for this permit.

\section{U.S. Department of the Army Permit - 33 CFR 325}

Discharging dredge and fill material into waters of the United States requires a permit from the U.S. Department of the Army, Corps of Engineers, before initiating the activity.

\section{EVALUATION:}

Project $W-465$ does not entail construction near the waters of the United States and is therefore not required to obtain this permit.

\section{Section 10 Permit - 33 CFR 322}

Permits are required before the construction of structures and the performance of other activities in or adjacent to navigable waters. Certain activities are covered by nationwide permits rather than individual Section 10 permits. However, any work in an area designated as a "study river" for possible inclusion in the Wild and Scenic River System, such as the Hanford Reach, must obtain an individual Section 10 permit.

\section{EVALUATION:}

This project does not entail construction of structures or performance of other activities in or adjacent to navigable waters. Therefore, this regulation and associated permits are not applicable to this project.

\section{Nationwide Permits - 33 CFR 330}

Nationwide Permits are general permits issued by the USACE designed to regulate with little, if any, delay or documentation, certain waterway activities having minimal impacts. These permits are not applicable for projects within a Wild and Scenic River study area. 


\section{EVALUATION:}

This project does not entail construction of structures or performance of other activities in or adjacent to navigable waters. Therefore, this regulation and associated permits are not applicable to this project.

\section{Hydraulic Projects Permit - WAC 220-110}

Any construction or other work that will change the natural flow of a river, including the addition of treated effluent waste water that will increase the natural flow, is required to obtain a hydraulic project approval from the State of Washington Department of Fisheries.

\section{EVALUATION:}

This project will not change the natural flow of a river, and will not add treated effluent waste water to a river. Therefore, this regulation and associated permits are not applicable to this project.

\section{Shoreline Development Permit - WAC 173-14 to -20}

A permit for developing the shoreline is required before construction for shorelines not federally owned, but under lease, easement, license, or other similar federal property rights short of fee ownership.

\section{EVALUATION:}

This project does not entail development of shoreline. Therefore, this reguiation and associated permits are not applicable to this project.

\section{Aquatic Lands Lease - WAC $332-30$}

Aquatic land activities that interfere with the general public's use of state-owned tidelands, shorelands, and beds of navigable waters, require authorization before construction from the State of Washington Department of Natural Resources by way of agreement, lease, permit, or other instrument(s).

\section{EVALUATION:}

This project will not interfere with the general public's use of stateowned tidelands, shorelands, and beds of navigable waters. Therefore, this regulation and associated permits are not applicable to this project. 
HNF-SD-ENV-EE-003、Rev. 0

Hanford Reach Study Act Notification - PL 100-605

Proposed construction within one-quarter mile of the Columbia River shoreline inside the Hanford Reach Area is subject to consultation and coordination with the National Park Service.

\section{EVALUATION:}

This project does not entail construction within one-quarter mile of the Columbia River shoreline inside the Hanford Reach Area. Therefore, this project is not subject to requirements for consultation and coordination with the National Park Service.

\section{Water Quality Modification Approval - WAC 173-201}

A permit, directive, or order, as appropriate, must be obtained from Ecology before undertaking an activity that will temporarily reduce water quality below the criteria and classifications established for the stream.

\section{EVALUATION:}

This project does not entail discharges to a navigable water and will not reduce water quality below the criteria and classification established for the Columbia River. Therefore, this regulation and associated permits are not applicable to this project.

\section{Ecology Certification of an EPA NPDES Permit - 40 CFR 121}

EPA may not issue an NPDES permit until a certification is granted or waived by Ecology. Ecology must certify that conditions necessary to ensure compliance with applicable federal and state water quality standards.

\section{EVALUATION:}

This project does not entail discharges to a navigable water. Therefore, this regulation and associated permits are not applicable to this project.

\section{Categorical Standards}

\section{Effluent Guideline and Standards - 40 CFR 405 to 471}

These regulations 7 ist industry categories associated with the NPDES permit program. The regulations prescribe effluent limitation guidelines for 
HNF-SD-ENV-EE-003 ReV. 0

existing sources, standards of performance for new sources, and pretreatment standards for new and existing sources.

\section{EVALUATION:}

This project does not entail discharges of liquid effluents to a navigable water. Therefore, this regulation and associated permits are not applicable to this project.

\section{DRINKING WATER SUPPLY}

Approval of Engineering Reports, Plans and Specifications - WAC 246-290

Approval of engineering reports, plans, and specifications for a drinking water supply system is required before construction.

\section{EVALUATION:}

This project does not entail modifications to a drinking water supply system. Therefore, this regulation and associated permits are not applicable to this project.

Drinking Water System Identification - WAC 246-290

New drinking water systems must obtain an identification number from the $\mathrm{DOH}$ before operation.

\section{EVALUATION:}

This project does not entail establishing a new drinking water system. Therefore, this regulation and associated permits are not applicable to this project.

\section{Drinking Water System Operator Certification - WAC 246-292}

Operators in direct responsible charge of certain public water systems must be examined and certified for their competency on state requirements and standards before operating the system. Systems requiring certified operators include systems with 100 services at any one time; or systems serving 25 or more persons where the water is supplied from a stream, lake, or other surface water source and the systems are required by law to use a water filtration system. 
HNF-SD-ENV-EE-003 ReV. 0

\section{EVALUATION:}

This project does not entail establishing a new drinking water system. Therefore, this regulation and associated permits are not applicable to this project.

\section{DANGEROUS WASTE}

Dangerous Waste Permit - WAC 173-303; 40 CFR 264, 265, 270

Facilities that treat, store, or dispose of regulated dangerous waste must obtain the necessary dangerous waste permits. Whether a waste is a regulated dangerous waste must be determined in accordance with WAC 173-303-070 designation procedures. Existing Hanford Facility. TSD units are obtaining permits in accordance with schedules and procedures identified in the Tri-Party Agreement. New Hanford Facility TSD units that are not identified in the Tri-Party Agreement will require development of a permitting plan to detail the strategies and schedules to be used for developing the necessary dangerous waste permits. This plan must be developed early in the project development phase. Strategies and schedules to be used for developing the necessary dangerous waste permits for new TSD units will need to be discussed with the appropriate regulatory agencies to gain their concurrence. 
HNF-SD-ENV-EE-003 ReV. 0

EVALUATION: The immobilized LAW will contain RCRA regulated constituents and hazardous components. It is anticipated that the LAW will carry the same waste codes as found in the DST Part $A$ and will require an approved RCRA permit for Dangerous Waste Storage of ILAW prior to operations. RCRA Part A, Form 3 for the existing Grout Vaults identifies that storage of Grout will occur in a surface impoundment and disposal will occur as a landfill. It is recommended that the Part $A$ be modified to reflect the revised waste form and function of the Grout vaults.

Transportation of Immobilized LAW from the private vendor to the Interim Storage facility must be accomplished in accordance with the dangerous waste transportation requirements of WAC 173-303.

Any dangerous waste that is generated during transport and storage of the ILAW during the normal operations of the facility will require management in a satellite accumulation "area, or in accordance with the 90-day accumulation provisions of WAC 173-303-200. In addition, any suspect waste materials awaiting sampling/analysis results will need to be managed as dangerous waste until analysis is received.

Any leachate collected during storage of ILAW in the modified Grout Vaults will need to be assessed against the designation requirements in WAC 173303. If the Teachate is determined to be dangerous waste either through designation through 1 isting or characteristics, then the effluent would be transported to Liquid Effluent Retention Facility (LERF) for processing through the 200 Area Effluent Treatment Facility and disposal at the State Approved Land Disposal Site in 200 West Area. If the leachate is not dangerous waste and complies with the acceptance criteria of the Treated Effluent Disposal Facility, the leachate could be disposed at that facility. Decisions that need to be made before the requirements for leachate can be determined are: i.) Designation of the ILAW, ij.) designation of leachate collected from the ILAW Interim Storage Facility.

If ILAW is a hazardous waste, disposal will be subject to the disposal provisions of WAC 173-303. Since disposal is not within the scope of Project $W-465$, requirements for disposal will be evaluated at a later date.

For additional information, please contact L. E. Borneman (373-2821) or 8. G. Eriandson $(372-2678)$.

Construction or Expansion of Surface Impoundments, Waste Piles, or Landfill Units - WAC-173-303-335

The construction or expansion of surface impoundments, waste piles, or landfills require submittal of the Construction Quality Assurance plans, programs, and certifications to Ecology. 
HNF-SD-ENV-EE-003 ReV. 0

\section{EVALUATION}

Project W-465 will modify the existing Grout Vauits, which are RCRA Treatment, Storage, and Disposal Unit. The existing RCRA Part A application, Form 3, states the operation and storage of the Grout Vaults will considered, for purposes of compliance with the Dangerous Waste regulations, a surface impoundment during waste storage, and a landfill for disposal purposes. Therefore, modifications to this unit will need to comply with the provisions of WAC 173-303-335.

It is recommended that the Part $A$ for the facility be modified to more accurately reflect the configuration of the ILAW.

For additional information contact L. E. Borneman (373-2821), or B. G. Erlandson (372-2678).

\section{SOLID WASTE}

\section{Solid Waste Handling Facility Permit - WAC 173-304}

Solid waste TSD sites or facilities (i.e., landfills, land spreading, piles, surface impoundments, and recycling facilities) must obtain approval from Ecology via the comprehensive solid waste plan, and a permit from the jurisdictional health department before construction. All nonradioactive, nondangerous solid waste disposal at Hanford shall be in accordance with the substantive requirements of the Washington Administrative Code (WAC) 173-304, "Minimum Functional Standards for Solid Waste Handling." WAC 173-351 does not apply to onsite DOE activities since the DOE is not a municipality.

\section{EVALUATION:}

The ILAW Interim Storage Facility is not subject to the disposal provisions of WAC 173-304 because it is not a 1 andfi11. All nonradioactive, nondangerous solid waste generated at the ILAW Interim Storage Facility will be disposed of in accordance with WAC 173-304.

If the ILAW were not a hazardous waste and if it was disposed in the Interim Storage Facility, disposal would be performed in accordance with this regulation (i.e., WAC 173-304). Since disposal is not within the scope of this evaluation, the environmental requirements for disposal will be performed at a later date.

For additional information contact L. E. Borneman (373-2821), or B. G. Erlandson (372-2678). 
HNF-SD-ENV-EE-003 ReV. 0

\section{UNDERGROUND STORAGE TANKS}

\section{UST Permit - WAC 173-360}

After July 1, 1991, no UST system, as defined in WAC 173-360, shall be operated without a valid permit from the regulatory agency.

\section{EVALUATION:}

Project W-465 does not contain an Underground Storage Tank for diesel fuel. If the design requirements change, adding a UST (i.e., establish a need for emergency back up systems and power), the environmental permits would need to be re-evaluated.

\section{ALL MEDIA}

\section{Floodplain/Wetland Assessment - 10 CFR 1022}

A. Floodplain/Wetland Assessment applies to all proposed floodplain/wetlands actions. A proposed action shall be designed to minimize potential harm to or within a floodplain. The assessment should be performed in conjunction with the NEPA process.

\section{EVALUATION:}

This project does not located in a floodplain or a wetland. Therefore, a wetland/floodplain assessment will not be performed for this project.

\section{CRR - 36 CFR 800}

A CRR shall be performed before initiating any potential surface-disturbing activities onsite, or if any modifications are planned for any facility with the potential for inclusion on the National Register of Historic Places. The request form to perform this assessment is located on Jetforms.

\section{EVALUATION:}

A Cultural Resource Review (CRR) has been performed for the existing Grout Vaults and the location of the proposed Immobilized Low Activity Waste Interim Storage facility. The results of this review are documented in the TWRS EIS. 
HNF-SD-ENV-EE-003 Rev. 0

\section{Excavation Permit - 36 CFR 800}

An excavation permit is required before initiating any potential surface-disturbing onsite activities.

\section{EVALUATION:}

Project $W-465$ will involve excavation and will require an excavation permit.

\section{Ecological Compliance Review - 10 CFR 1021; 50 CFR 402.6; DOE Order 5484.1}

A site survey should be performed to identify, if any: plant or animal species protected under the Endangered Species Act; candidates for such protection; species 1 isted as threatened, endangered, candidate, sensitive, or monitored by the state of Washington; and species protected under the Migratory Bird Treaty Act. Also assessed is whether the planned activities have the potential to disturb any priority habitats and/or species identified in the survey. The request form to perform this review (along with a CRR) is WordPerfect macro GEF271. This review al so fulfills the NEPA ecological/biological review requirement.

\section{EVALUATION:}

An ecological/biological review was performed on the existing Grout Vaults and the immobilized low activity waste interim storage facility. This review was documented in the TWRS EIS. Because a significant amount of time has elapsed since any waste was placed in the Grout Vaults, the original ecological/biological review will need to be assessed to determine if additional assessments or reviews are needed.

Preoperational Monitoring of Facilities, Sites, and Operations DOE Order 5400.1

Note: For more information see the Environmental Compliance Manual WHC-CM-7-5, Section 5.0, 5.4.2.1.g \& h, Section 8.0,8.5.1.7, and Section 9.0, 9.3.1.3.

An environmental study shall be conducted before start-up of a site, facility, or process that has the potential for significant adverse environmental impact. This study should begin not less than one year and preferably two years before start-up, so seasonal changes can be evaluated. This study precedes the conceptual design report and can include data acquired in the site selection process, excavation permit process, and NEPA/SEPA process. 
HNF-SO-ENV-EE-003 Rev. 0

\section{EVALUATION:}

TWRS Phase I Privatization Site environmental Baseline and Characterization Plan, HNF-SD-TWR-EV-001, has been developed. This plan presents a program to characterize and establish an environmental baseline for the TWRS Phase I site, feed tanks, and waste transfer corridors. This plan focuses on characterizing the surface and near surface vadose zone and data collection supporting the development of the preoperational baseline. This document provides a plan for the following activities:

1. Characterize the TWRS Phase I Demonstration Site surface area and near surface vadose zone;

2. Screen the TWRS Phase I Demonstration Site and waste transfer corridor for shallow buried material or near surface contamination from past activities; and

3. Develop an environmental baseline for the TWRS Phase I Demonstration Site and waste transfer corridors and feed tanks.

It is anticipated that the implementation of this plan will satisfy the requirements for pre-operational monitoring. For additional information, please call L. E. Borneman $(373-2821)$ or B. G. Erlandson (373-3678).

\section{Radiation Protection Standards - DOE Order 5400.5}

This DOE Order establishes standards and requirements that must be followed to protect members of the public and environment against undue risk from radiation. The general environmental protection program requirements are established in DOE Order 5400.1. DOE Order 5400.1 requires that all DOE Sites prepare an environmental monitoring plan. DOE/RL 91-50, Environmental Monitoring P1an, includes DOE/EH-0173T, Environmental Regulatory Guide for Radiological Effluent Monitoring and Environmental Surveillance, which provides specific guidance regarding environmental monitoring activities.

EVALUATION: A monitoring plan should be developed for the facility. For additional information, please call L. E. Borneman (373-2821) or B. G. Erlandson $(373-3678)$. 


\section{DISTRIBUTION SHEET}

\begin{tabular}{|c|c|c|c|c|c|}
\hline \multirow{2}{*}{$\begin{array}{l}\text { To } \\
\text { Distribution }\end{array}$} & \multirow{2}{*}{\multicolumn{3}{|c|}{$\begin{array}{l}\text { From } \\
\text { M. L. Deffenbaugh. }\end{array}$}} & \multicolumn{2}{|c|}{ Page 1 of 1} \\
\hline & & & & \multicolumn{2}{|c|}{ Date $9 / 3 / 97$} \\
\hline \multicolumn{4}{|c|}{ Project Title/Work Order } & \multicolumn{2}{|c|}{ EDT No. 605603} \\
\hline PERMITTING PLAN FOR THE & ZED LOW-ACTIVI & $Y$ WASTE & OJECT & \multicolumn{2}{|c|}{ ECN No. } \\
\hline Name & MSIN & $\begin{array}{c}\text { Text } \\
\text { With All } \\
\text { Attach. }\end{array}$ & Text Only & $\begin{array}{l}\text { Attach./ } \\
\text { Appendix } \\
\text { Only }\end{array}$ & $\begin{array}{l}\text { EDT/ECN } \\
\text { Only }\end{array}$ \\
\hline
\end{tabular}

V. L. Armstrong

H5-03

H. L. Boston

H5-24

D. J. Carrel1

R1-51

M. W. Cline

H6-26

M. L. Deffenbaugh

R1-90

M. P. Delozier

S7-84

B. G. Erlandson

R1-51

C. J. Grando

R1-51

J. D. Guberski

R1-51

C. C. Haas

S7-51

P. E. Lamont.

E. E. Mayer

S7-53

J. E. Mercado

R2-36

R. K. P'Pool

$\mathrm{HI}-15$

J. A. Voogd

S5-03

H5-03

Central Files

A3-88 